\title{
Distal Dendritic Enrichment of HCN1 Channels in Hippocampal CA1 Is Promoted by Estrogen, but Does Not Require Reelin
}

\author{
Maurice Meseke, ${ }^{1}$ Florian Neumüller, ${ }^{1}$ B Bianka Brunne, ${ }^{2}$ Xiaoyu Li, ${ }^{1}$ Max Anstötz, ${ }^{1}$ (DTheresa \\ Pohlkamp, ${ }^{3}$ Meike M. Rogalla, ${ }^{1}$ Joachim Herz, ${ }^{3}{ }^{-}$Gabriele M. Rune, ${ }^{1}$ and Roland A. Bender ${ }^{1}$
}

https://doi.org/10.1523/ENEURO.0258-18.2018

${ }^{1}$ Institute of Neuroanatomy, University Medical Center, Hamburg 20246, Germany, ${ }^{2}$ Institute of Structural Neurobiology, Center of Molecular Neurobiology, Hamburg 20246, Germany, and ${ }^{3}$ Department of Molecular Genetics, University of Texas Southwestern Medical Center, Dallas, TX 75390

\begin{abstract}
HCN1 compartmentalization in CA1 pyramidal cells, essential for hippocampal information processing, is believed to be controlled by the extracellular matrix protein Reelin. Expression of Reelin, in turn, is stimulated by $17 \beta$-estradiol (E2). In this study, we therefore tested whether E2 regulates the compartmentalization of HCN1 in CA1 via Reelin. In organotypic entorhino-hippocampal cultures, we found that E2 promotes HCN1 distal dendritic enrichment via the G protein-coupled estrogen receptor GPER1, but apparently independent of Reelin, because GST-RAP, known to reduce Reelin signaling, did not prevent E2-induced HCN1 enrichment in distal CA1. We therefore re-examined the role of Reelin for the regulation of HCN1 compartmentalization and could not detect effects of reduced Reelin signaling on HCN1 distribution in CA1, either in the (developmental) slice culture model or in tamoxifen-inducible conditional reelin knockout mice during adulthood. We conclude that for HCN1 channel compartmentalization in CA1 pyramidal cells, Reelin is not as essential as previously proposed, and E2 effects on HCN1 distribution in CA1 are mediated by mechanisms that do not involve Reelin. Because HCN1 localization was not altered at different phases of the estrous cycle, gonadally derived estradiol is unlikely to regulate HCN1 channel compartmentalization, while the pattern of immunoreactivity of aromatase, the final enzyme of estradiol synthesis, argues for a role of local hippocampal E2 synthesis.
\end{abstract}

Key words: Aromatase; estrogen; GPER1; hippocampus; neurosteroid; Reelin

\section{Significance Statement}

Mechanisms of learning and memory require a fine-tuned interplay between ion channels on hippocampal neurons. Among these, CA1 pyramidal cells have a crucial position, as they integrate information from various hippocampal and extrahippocampal sources. Identifying factors that influence the function of ion channels, such as the HCN1 channels, which filter entorhinal synaptic input, may therefore help to better understand processes that underlie learning and memory. Here we show that the dendritic localization of HCN1 channels, a critical determinant of their function, is influenced by estrogen (E2), thus bringing attention to the modulatory roles of sex hormones on hippocampal information processing, which are yet poorly understood.

Received July 1, 2018; accepted August 26, 2018; First published September 27, 2018.

The authors declare no competing financial interests.
Author contributions: MM, FN, BB, XL, and MMR performed research; MA, TP, and JH contributed unpublished reagents/analytical tools; GMR and RAB designed research; RAB wrote the paper. 


\section{Introduction}

Hyperpolarization-activated cyclic nucleotide-gated (HCN) channels generate the h-current $\left(I_{h}\right)$, a critical determinant of the resting membrane potential in neurons (Pape, 1996; Robinson and Siegelbaum, 2003). A variety of additional functions of $I_{h}$ in neurons exist, but these depend strongly on the subcellular localization of the channels (Bender and Baram, 2008; Shah, 2014). For instance, in cortical pyramidal cells, HCN channels are strikingly enriched in the distal dendrites, but almost absent in the proximal dendritic and somatic compartments (Lörincz et al., 2002; Notomi and Shigemoto, 2004; Brewster et al., 2007). In hippocampal CA1, this distal dendritic enrichment of $\mathrm{HCN}$ channels in the pyramidal neurons filters synaptic input from the perforant path (Vaidya and Johnston, 2013) and supports the temporal integration of excitation in the CA1 pyramidal cells (Magee, 1999; Poolos et al., 2002). As HCN channels thus markedly influence hippocampus-dependent learning and memory (Nolan et al., 2004), an understanding of the mechanisms that govern their subcellular localization is of substantial interest, and contributing factors have previously been identified (Piskorowski et al., 2011; Lewis et al., 2011; Wilkars et al., 2012); however, without yet solving the question comprehensively.

In this context, a recent study proposed that the extracellular matrix protein Reelin promotes the distal dendritic enrichment of channels of the HCN1 subtype, the predominant cortical HCN isoform, in pyramidal cells (Kupferman et al., 2014). Reelin is best known for its role in brain development, during which it controls neuronal migration and cortical lamination (D'Arcangelo et al., 1995; Ogawa et al., 1995; Tissir and Goffinet, 2003; Förster et al., 2006). However, as some neurons continue to express Reelin in adult brain, its functions go beyond developmental roles and include the regulation of synaptogenesis and long-term potentiation (Herz and Chen, 2006; Bock and May, 2016; Lee and d'Arcangelo, 2016). The canonical Reelin signaling cascade involves the binding of a Reelin dimer to low-density lipoprotein receptors, the APOE receptor 2 (APOER2), and the very-low-density lipoprotein (VLDL) receptor, resulting in phosphorylation of the adaptor protein Disabled 1 (Dab1), which activates a variety of downstream signaling molecules (Bock and May, 2016; Lee and d'Arcangelo, 2016). Kupferman et al.

Funding sources: Deutsche Forschungsgemeinschaft (RAB: Be4107/2-1, Be4107/3-1; GMR: Ru436/6-1). JH is supported by grants from the NHLBI, NINDS and NIA, the Bluefield Project and the Brightfocus Foundation.

Present address: Maurice Meseke, Dept. of Anatomy and Molecular Brain Research, University of Bochum, 44780 Bochum, Germany; Meike M. Rogalla, Dept. of Neuroscience, University of Oldenburg, 26111 Oldenburg, Germany.

Acknowledgments: The authors thank H. Herbort, K. Sander, H. Hamann, and J. Graw for their excellent technical support.

Correspondence to Roland A. Bender, PhD, Institute of Neuroanatomy, University Medical Center Hamburg, Martinistr. 52, 20246 Hamburg, Germany. E-mail: r.bender@uke.de.

https://doi.org/10.1523/ENEURO.0258-18.2018

Copyright (C) 2018 Meseke et al.

This is an open-access article distributed under the terms of the Creative Commons Attribution 4.0 International license, which permits unrestricted use, distribution and reproduction in any medium provided that the original work is properly attributed.
(2014) showed that a viral knockdown of Dab1 results in a reduction of $\mathrm{HCN} 1$ channels and $\mathrm{I}_{\mathrm{h}}$ in the distal dendritic compartment of CA1 and neocortical pyramidal cells in vivo. Similar results were observed in organotypic hippocampal cultures, if receptor-associated protein (RAP), an inhibitor of low-density lipoprotein receptor-related proteins (LRPs, including VLDL and APOER2; Herz et al., 1991; Bu and Schwartz 1998; Gong et al., 2007), was applied. The authors thus concluded that Reelin, acting via Dab1, is essential for the striking enrichment of HCN1 in the distal dendritic compartment of the pyramidal cells (Kupferman et al., 2014).

We have previously shown that the expression of Reelin in hippocampus is enhanced by $17 \beta$-estradiol (E2; Bender et al., 2010), the most potent estrogen, either synthesized in the gonads or locally produced and released as a neurosteroid from hippocampal neurons (Prange-Kiel et al., 2003; Kretz et al., 2004). We therefore reasoned that E2 should also influence the distribution of HCN1 channels in CA1, via the stimulation of Reelin expression. Here we tested this hypothesis using organotypic entorhinohippocampal cultures to determine the effects of E2 on HCN1 distribution in CA1 and to examine whether these effects involve Reelin. Our data strongly suggest that E2 regulates $\mathrm{HCN} 1$ channel localization in CA1 pyramidal cells but argue against an involvement of Reelin. Data from an inducible conditional reelin-knockout mouse line (Lane-Donovan et al., 2015) further question an essential role of Reelin for the distal dendritic enrichment of HCN1 channels in pyramidal neurons, as was previously proposed (Kupferman et al., 2014).

\section{Material and Methods}

\section{Organotypic cultures}

Combined entorhino-hippocampal slice cultures, preserving perforant path connectivity, were used for these studies. Briefly, 5-d-old (P5) rats (Wistar, breeding stock from Charles River, RRID:RGD_737929) were decapitated; the hippocampus, with entorhinal cortex (EC) attached, was dissected out, gently placed on the platform of a Mcllwain tissue chopper, and sliced perpendicular to the hippocampal longitudinal axis $(400 \mu \mathrm{m})$. Slices were then transferred to preparation solution [minimal essential medium (MEM) supplemented with $2 \mathrm{~mm}$ glutamine, $\mathrm{pH}$ 7.3], but care was taken that slices adjacent to each other stayed attached. From these grouped slices, pairs or triples were isolated, of which each slice was transferred to a separate membrane insert (Millicell CM, 0.4- $\mu \mathrm{m}$ culture plate inserts, $30 \mathrm{~mm}$ diameter; Merck Millipore) and subjected to a different experimental condition (i.e., one slice of each pair or triple served as a vehicle-treated control, whereas the corresponding slices were subjected to experimental treatment). Cultures were maintained in vitro in a $37^{\circ} \mathrm{C} 95 \% / 5 \% \mathrm{CO}_{2}$ humidified incubator. Incubation medium consisted of 50\% MEM, 25\% Hanks' balanced salt solution, and $25 \%$ heat-inactivated horse serum, supplemented with $2 \mathrm{~mm}$ glutamine, $30 \mathrm{~mm}$ glucose, $0.044 \% \mathrm{NaHCO}_{3}, 100$ units $/ \mathrm{ml}$ penicillin, and 100 $\mu \mathrm{g} / \mathrm{ml}$ streptomycin (all tissue culture reagents were obtained from Invitrogen/Thermo Fisher Scientific). Medium 
was changed every second day. For immunohistochemistry, experimental treatment of the cultures usually started after 5 days in vitro (DIV) and lasted for 6 d (DIV5-DIV11), during which the medium of the experimental groups was supplemented with either E2 (100 nM, in $\mathrm{H}_{2} \mathrm{O}$; Sigma, Cat\# E4389), E2 (100 nM) + G36 (20 nM, in DMSO; Tocris, Cat\# 4759), G1 (20 nM, in DMSO; Tocris, Cat\# 3577), 4,4', 4"-(4-propyl-[1H]pyrazole-1,3,5-triyl)trisphenol (PPT; $100 \mathrm{nM}$, in DMSO; Tocris, Cat\# 1426), diarylpropionitrile (DPN; 100 nM, in DMSO; Tocris, Cat\# 1495), receptor-associated protein-glutathioneS-transferase (GST-RAP, $10 \mu \mathrm{g} / \mathrm{ml}$; see generation below), mouse anti-Reelin (CR-50) antibodies $(2 \mu \mathrm{g} / \mathrm{ml}$; MBL International, Cat\# D223-3, RRID:AB_843523) or E2 (100 nM) + GST-RAP $(10 \mu \mathrm{g} / \mathrm{ml})$. For the controls, medium was supplemented with equivalent amounts of vehicle or suitable neutral molecules (GST or random mouse lgGs, respectively). In one experiment, cultures were supplemented with GST-RAP or GST $(50 \mu \mathrm{g} / \mathrm{ml})$ for only $48 \mathrm{~h}$ (DIV8-DIV10). Generally, at the end of treatment, cultures were fixed for $1 \mathrm{~h}$ with $4 \%$ paraformaldehyde (PFA) in PBS, then cryoprotected with $25 \%$ sucrose ( $2 \mathrm{~h}$ ) and frozen on dry ice for immunohistochemistry (see below).

Additionally, the following experimental treatments were performed for Western blot analyses. (1) Cultures were incubated with E2 (100 nM), G1 (20 nM), or vehicle for 6 d (DIV5-DIV11), then harvested and deep-frozen for analysis of HCN1 and GPER1 expression levels. (2) On DIV10, cultures were incubated with GST-RAP or GST (10 $\mu \mathrm{g} / \mathrm{ml}$ ) for 24 h. On DIV11, $50 \mu$ l of Reelin-conditioned medium (see preparation below) were placed on top of each culture for $30 \mathrm{~min}$. Slices were then harvested and immediately deep frozen in nitrogen for analysis of Dab1 protein expression (Dab1) and Dab1 phosphorylation (pDab1).

\section{Animals}

For analyses in vivo, juvenile rats (Wistar, as above) with an equivalent age to the cultures (P16) and adult mice (P90-P100; C57BL/6J, breeding stock from Jackson Laboratory, RRID:IMSR_JAX:000664) were used. The animals were housed in the University Hamburg, Medical Center animal facility under controlled conditions and had access to food and water ad libitum. For immunohistochemistry, animals were deeply anesthetized using a ketaminexylazine mixture (ketamine $12 \mathrm{mg} / \mathrm{ml}$, xylazine $0.16 \%$ in saline, i.p.) and transcardially perfused with $4 \%$ PFA. Subsequently, the brains were removed from the skull, postfixed for $4 \mathrm{~h}$ in $4 \%$ PFA, cryoprotected with $25 \%$ sucrose for $>48 \mathrm{~h}$, and deep frozen in $-50^{\circ} \mathrm{C}$ isopentane. From the adult female mice, the estrous cycle stage was determined postmortem using vaginal smears (Hoglund, 1972; Byers et al., 2012). All animal experiments were performed according to legal guidelines and were approved by the institutional committees for the care and use of laboratory animals (University Hamburg, Animal Care Committee, ORG 804). Additionally, male tamoxifeninducible reelin-knockout mice (Reelin cKO) were examined. These mice were generated and held at the University of Texas, Southwestern Medical Center (Dallas, TX) by crossing an inducible Cre recombinase-express- ing line (CAG-CreERT2) with mice in which the first exon of the reelin-gene was flanked with loxP sites (Re/ ${ }^{\text {flox/flox; }}$ Lane-Donovan et al., 2015). Control mice [wild type (WT)] were CAG-CreERT2-negative. At 2 months of age, both the Reelin CKO and the control mice received daily intraperitoneal injections for $5 \mathrm{~d}$ of tamoxifen $(135 \mathrm{mg} / \mathrm{kg}$; Sigma), dissolved in sunflower oil. Mice were perfused at 7-8 months of age, and brains were sent to the University of Hamburg for immunohistochemistry $(\mathrm{IHC})$ analysis (see below).

\section{Immunohistochemistry}

Brains and slice cultures were cut on a cryotome, and sections were collected in PBS. Subsequently, brain sections $(25 \mu \mathrm{m})$ were processed "free-floating," whereas slice culture sections $(20 \mu \mathrm{m})$ were mounted to glass slides (sections from grouped cultures always on the same slide) and dried, before being processed. For IHC, both brain and culture sections were preincubated with $3 \%$ normal goat serum (in PBS) for $1 \mathrm{~h}$ at room temperature (RT), then primary antibodies were applied for $24 \mathrm{~h}$ at $4^{\circ} \mathrm{C}$. The following primary antibodies were used: rabbit polyclonal anti-HCN1 (1:500; Merck Millipore, Cat\# AB5884, RRID:AB_2115002), rabbit polyclonal anti-GPER1 (1:400; Abcam, Cat\# ab39742, RRID:AB_1141090), mouse monoclonal anti-Reelin (1:500; Merck Millipore, Cat\# MAB5366, RRID:AB_2285132), mouse monoclonal antitetratricopeptide repeat-containing Rab8b interacting protein (TRIP8b), constant region (1:1000; NeuroMab, clone N212/17, RRID:AB_10675453), rabbit polyclonal antiaromatase (1:3000; Abcam, Cat\# ab191093, RRID: AB_2737021; directed against amino acids $455-476$ of rat aromatase), rabbit polyclonal anti-aromatase (1:200; BIOSS, Cat\# bs-1292R, RRID:AB_10880885; directed against amino acids $65-120$ of human aromatase), and rabbit polyclonal anti-aromatase (1:1200; directed against amino acids 488-502 of mouse aromatase; gift of Dr. I. Azcoitia, Madrid; Yague et al., 2006; RRID:AB_2631184). After primary antibody incubation, sections were washed twice in PBS, before secondary antibodies were applied for $3 \mathrm{~h}$ at RT: Alexa Fluor 488-coupled goat anti-rabbit IgGs (1:500; Invitrogen, Cat\# A-11034, RRID:AB_2576217) or Alexa Fluor 546-coupled goat anti-mouse IgGs (1:500; Invitrogen, Cat\# A-11030, RRID:AB_2534089). Sections were washed again and treated for $1 \mathrm{~min}$ with 4,6-diamidino-2-phenylindol (DAPI, Sigma). Free-floating sections were then mounted on glass slides. All sections were embedded with fluorescent mounting medium (Dako), coverslipped, and subsequently viewed and photographed using fluorescence microscopy (Keyence BZ9000: HCN1, GPER1, TRIP8b, Reelin) or confocal microscopy (Olympus FV1000: aromatase). To control for specificity, sections were processed according to the protocol above with primary antibodies omitted.

\section{Western blots}

For protein expression analyses of HCN1, GPER1, total Dab1, and phosphorylated Dab1 (pDab1), tissue was homogenized in ice-cold RIPA lysis buffer (1\% NP40, 0.1\% SDS, $0.5 \%$ Na-deoxycholate, protease inhibitor, and phosSTOP; Roche). Lysates were cleared by centrifugation at $4^{\circ} \mathrm{C}$ and $13,000 \times g$ for $30 \mathrm{~min}$. From each sample, 
30-50 $\mu \mathrm{g}$ was diluted in water and $5 \times$ Laemmli buffer (62.5 mM Tris, pH 6.8; 2\% SDS; $10 \%$ glycerol; 5\% 2-mercaptoethanol; $0001 \%$ bromophenol blue) to a final volume of $12.5 \mu \mathrm{l}$. The samples were heated to $95^{\circ} \mathrm{C}$ for $5 \mathrm{~min}$ and then immediately cooled on ice. Subsequently, samples from experimentally treated cultures were loaded side-byside with the corresponding control cultures, then separated on a $10 \%$ polyacrylamide gel by gel electrophoresis (Invitrogen) in Laemmli running buffer (10\% SDS, 3\% Tris, $14 \%$ glycine) and transferred electrophoretically to polyvinylidene fluoride membranes with transfer buffer $(0.02 \%$ SDS, 0015\% Tris, 0.08\% glycine). For blotting, the membranes were blocked with $5 \%$ bovine serum albumin (Dab1, pDab1) or milk powder (HCN1, GPER1) in PBS at $\mathrm{RT}$ for $1 \mathrm{~h}$ and incubated with primary antibodies: guinea pig polyclonal anti-HCN1 (1:500; Santa Cruz Biotechnology, Cat\# sc-19706; this antibody is not available anymore; patterns were identical to those generated by the rabbit-anti-HCN1 that was used for IHC, see above), rabbit polyclonal anti-GPER1 (1:400), rabbit polyclonal anti-Dab1 (1:1000; Rockland Immunochemicals, Cat\# 100-401-225, RRID:AB 2245755), or mouse monoclonal anti-phosphotyrosine (1:1000; Merck Millipore, clone 4G10, Cat\# 05-321, RRID:AB_309678) in blocking solution at $4^{\circ} \mathrm{C}$ overnight. Mouse monoclonal anti-GAPDH (1: 2000; Ambion/Thermo Fisher Scientific, Cat\# AM4300, RRID:AB_437392) was co-applied for loading control. Secondary antibodies, conjugated with alkaline phosphatase, were applied for $1 \mathrm{~h}$ at RT (Western Breeze Chemiluminescent Immunodetection Kit, Invitrogen). The immunoreaction was visualized by enhanced chemiluminescence (FUSION-SL4 advanced imaging system; Vilber Lourmat Labtech).

\section{Generation of GST-RAP}

The pGEX-kg vector was generated from the initial pGEX-2T vector (GE Healthcare) by cutting it with EcoR1 to insert a new linker. To generate the required pGEX-kgRAP plasmid, cDNA (rat) of receptor-associated binding protein (RAP) was cloned via intersections EcoR1 and Hindlll into the pGEX-kg vector (Herz et al., 1991). DH5 $\alpha$ bacteria were transformed with the pGEX-kg-RAP with a heat shock at $41^{\circ} \mathrm{C}$ for $42 \mathrm{~s}$ followed by cooling down on ice. Bacteria were plated on ampicillin agar plates, which were incubated overnight at $37^{\circ} \mathrm{C}$, then stored at $4^{\circ} \mathrm{C}$. For subsequent procedure, liquid cultures were inoculated with transformed bacteria. RAP expression was induced by isopropyl- $\beta$-D-thiogalactopyranoside. After $5 \mathrm{~h}$, bacteria were harvested by centrifugation. Cells were lysed with lysozyme and Triton X-100 and by mechanical stress. Proteins were stabilized with dithiothreitol. Extraction and purification were performed with glutathione-Sepharose columns. After elution of GST-RAP, protein concentration was determined by Bradford protein assay. Final protein concentrations were adjusted to $1 \mathrm{mg} / \mathrm{ml}$, and aliquots were stored at $-20^{\circ} \mathrm{C}$.

\section{Preparation of Reelin-conditioned medium}

HEK-293 cells were stably transfected with a plasmid containing full-length Reelin cDNA (D'Arcangelo et al.,
1997). Serum-free supernatants containing secreted Reelin were collected as described by Förster et al. (2002).

\section{Analysis (IHC)}

For quantitative analysis of HCN1 distribution in slice cultures, sections from grouped cultures (pairs or triples, see above) were mounted to the same slide and immunostained for HCN1. Subsequently, CA1 was photographed at $100 \times$ magnification using identical illumination for each section by a photographer who was blinded to the experimental condition. For further analysis (also blinded), one picture per culture was chosen. Using Fiji (ImageJ) software (National Institutes of Health), three lines were then drawn in CA1, from the pyramidal cell layer to the hippocampal fissure, at defined positions (illustrated in Fig. 1E): (a) above the crest of the granule cell layer, (b) above the midpoint between crest and tip of the granule cell layer, and (c) above the tip of the granule cell layer. Along the proximal-distal axis, these lines were subdivided into five equal segments (1-5), with segment 1 adjoining the pyramidal cell layer (most proximal) and segment 5 adjoining the hippocampal fissure (most distal). Integrated line density (indicated as arbitrary units, $A U$ ) was determined along these lines using NIH Fiji software. Background signal, determined in the molecular layer of the dentate gyrus, was subtracted. Subsequently, the proportion of HCN1 signal per segment (percent of total HCN1 AU) was calculated at each of the three positions. Data from the three positions were then averaged to obtain one representative value for each segment per analyzed culture (each culture equaling $n=1$ ). The illustrated scheme (Fig. 1E) was also used for the analysis of HCN1 distribution in Reelin CKO versus WT mice ( $n=5$, each) and in adult male and female mice for the analysis of estrus cycle effects $(n=6$, each group). For these analyses, three topically defined coronal sections (corresponding to positions 71,74 , and 77 of the Allen Mouse Brain Atlas, http://mouse.brain-map.org/static/ atlas) were selected per animal, and left and right hippocampus was analyzed in each section, resulting in a total of six values per segment, from which the mean was calculated (denoting one representative value per animal, equaling $n=$ 1). In addition, from the adult female mice ( $n=6 ; 3$ in proestrus, 3 in diestrus) another set of sections (as above) was chosen to quantify aromatase immunosignal in CA1 stratum lacunosum-moleculare $(\mathrm{s} / \mathrm{m})$ relative to expression in stratum radiatum (sr). For this purpose, sections were immunostained with rabbit polyclonal anti-aromatase (Abcam, see above). CA1 was then photographed at $100 \times$ magnification with confocal microscopy, and the integrated density of aromatase immunosignal was determined, both in sr and slm, at three defined positions above the granule cell layer (positions $a, b$, and c; as above) using NIH Fiji software. Subsequently, the mean integrated density for each layer was determined, and density in sIm was compared to density in the corresponding sr for each animal. Data are presented as aromatase in $\mathrm{slm} / \mathrm{sr}(\%)$.

\section{Quantitative Western blots}

For quantitative analyses of HCN1, GPER1, Dab1, and pDab1 in organotypic slices, all cultures deriving from one pup that had been subjected to the same treatment (usually 4-7) were pooled, and tissue was prepared for West- 

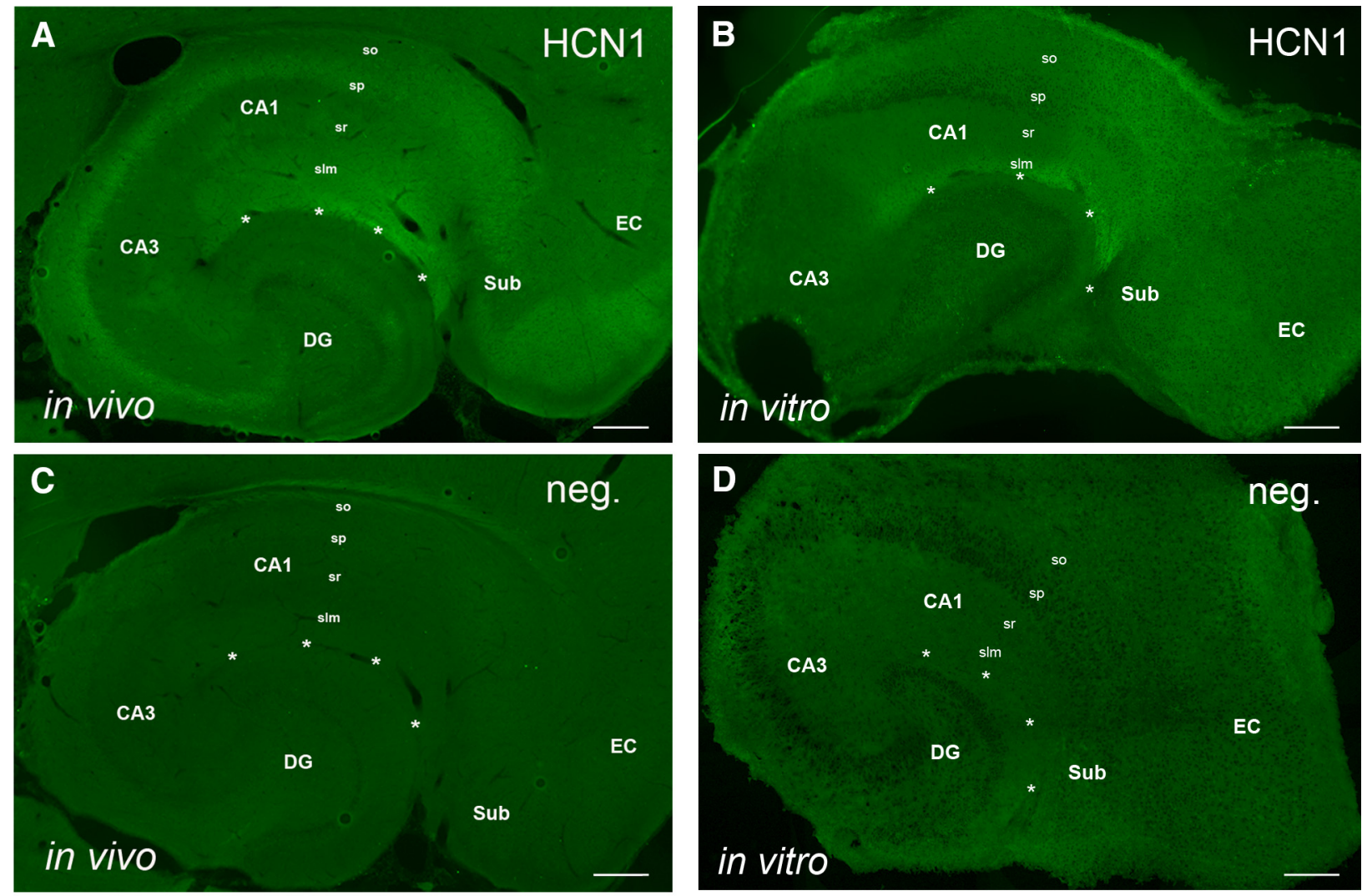

E

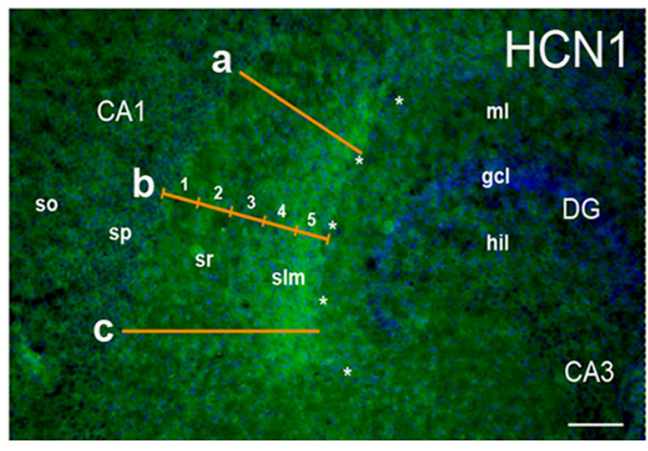

H

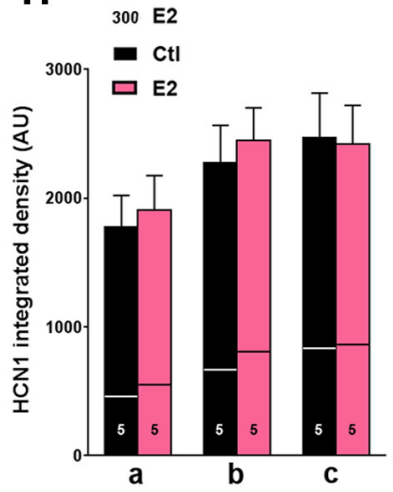

F

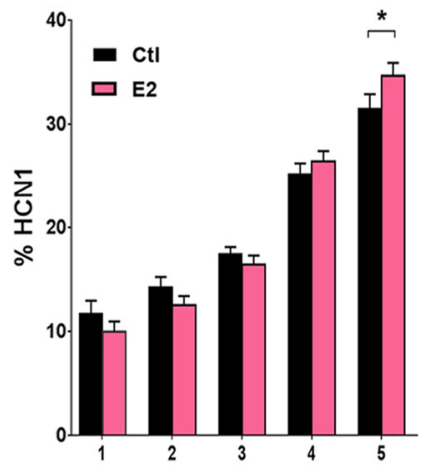

J
G

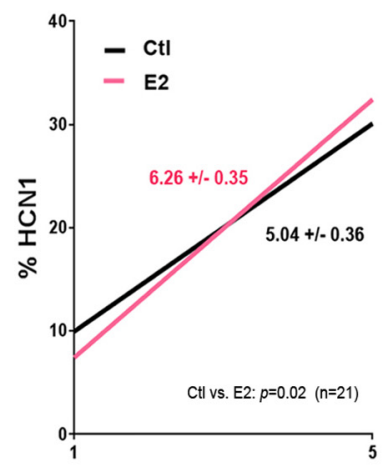

K
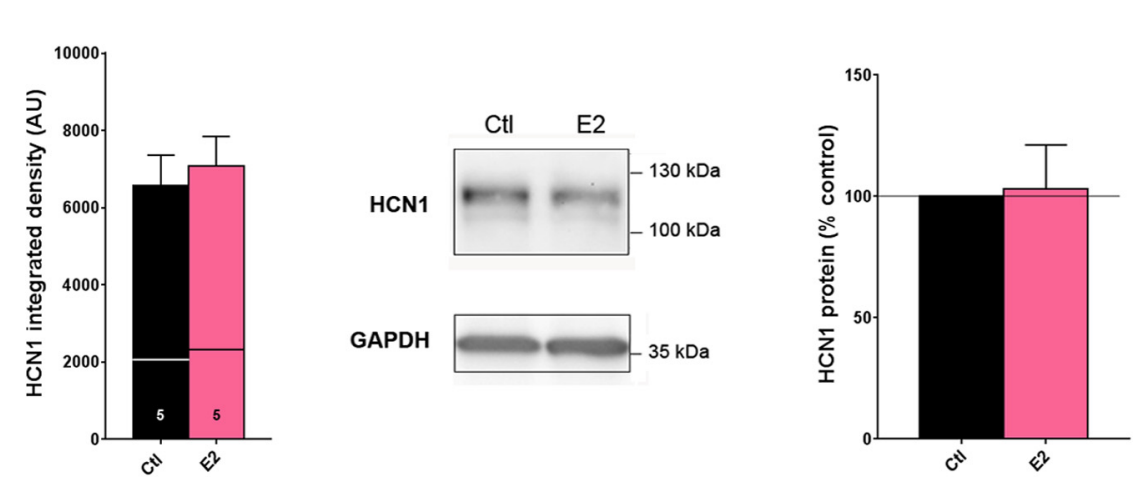

Figure 1. Estrogen (E2) promotes the distal dendritic enrichment of HCN1 in CA1. $\boldsymbol{A}, \boldsymbol{B}$, Comparison of HCN1 immunoreactivity (green) in a horizontal hippocampal section from a 16-d-old rat (in vivo, $\boldsymbol{A}$ ) and in a section from an entorhino-hippocampal 


\section{continued}

organotypic slice culture prepared on postnatal day 5, and kept for $11 \mathrm{~d}$ in vitro (DIV11, B). Note that the pattern in vitro reproduces the pattern in vivo, including HCN1 enrichment in distal CA1. C, $\boldsymbol{D}$, No pattern was observed in vivo (C) and in vitro $(\boldsymbol{D})$, when the primary antibody was omitted. $\boldsymbol{E}$, Scheme for the analysis of HCN1 distribution in CA1: three lines (positions $a, b, c$ ), connecting stratum pyramidale (sp) and the hippocampal fissure (asterisks) were subdivided into five equal segments, and relative HCN1 immunosignal (integrated line density) within each segment was determined. $\boldsymbol{F}, \boldsymbol{G}$, Results are illustrated as individual column bars $(\boldsymbol{F})$ or linear regression analysis (slope) of the density increase from segment 1-5 (G). Note that E2 treatment from DIV5-11 increased the relative HCN1 immunosignal in segment 5 significantly $(\boldsymbol{F})$ and resulted in a significantly steeper slope, indicating E2-induced distal dendritic enrichment of $\mathrm{HCN} 1(\boldsymbol{G}) . \boldsymbol{H}, \boldsymbol{I}$, Comparison of the integrated density of HCN1 immunosignal (arbitrary units, AU) at analysis positions $a, b$, and $c(\boldsymbol{H})$, or summarized for all positions (I) did not reveal differences of total HCN1 immunosignal between E2- and vehicle-treated cultures at any of the positions chosen for analysis. Horizontal lines demarcate the proportion of HCN1 signal in segment 5 at each position (a: $26 \% \pm 1 \%$ vs. $31 \% \pm 2 \%, b: 30 \% \pm 2 \%$ vs. $33 \% \pm 2 \%, c: 34 \% \pm 3 \%$ vs. $36 \% \pm 2 \%$, in vehicleand E2-treated cultures, respectively). J, Representative Western blots for HCN1 (upper lane) or GAPDH for loading control (lower lane), using tissue from cultures treated with either vehicle (left bands, Ctl) or E2 (right bands): no E2-effect on total HCN1 protein expression within the cultures was evident. Note the characteristic double bands for HCN1, at 105 and $125 \mathrm{kDa}$, indicative of differential glycosylation of HCN1 (Zha et al., 2008). Data are quantified in $\boldsymbol{K}$. Scale bars: $250 \mu \mathrm{m}(\boldsymbol{A}-\boldsymbol{D}), 100 \mu \mathrm{m}(\boldsymbol{E})$. CA, cornu ammonis; DG, dentate gyrus, EC, entorhinal cortex; hil, hilus; gcl, granule cell layer; ml, molecular layer; so, stratum oriens, sr, stratum radiatum; Sub, subiculum. The section in $\boldsymbol{C}$ has been counterstained with DAPI (blue).

ern blotting as described above (thus, each pup equaling $n=1$ ). Signal intensity of bands was quantified by densitometry, using NIH Fiji software and GAPDH for loading control. Subsequently, data from the experimentally treated cultures were compared to the data from the corresponding controls (running side by side) and presented as percent of control.

\section{Statistics}

Relative HCN1 distribution (percent of total HCN1) in each of the five segments, resulting from integrated line density measurements, is illustrated in column bar graphs. Two types of statistical tests were used to analyze the data: (1) Wilcoxon matched pairs signed rank test (if two experimental groups were compared) or Friedman test, followed by Dunn's multiple comparison test (if three groups were compared) were applied to test for differences within individual segments, if data were paired and nonparametric (i.e., from slice cultures). For unpaired data, such as those resulting from analyses in mice, Mann-Whitney test (two groups: Reelin cKO versus WT) or Kruskal-Wallis test, followed by Dunn's multiple comparison test [three groups: estrus cycle analysis (male versus proestrus and diestrus females)] were used. (2) In addition, to pinpoint comprehensive trends, a comparison of the slopes of the gradients from segments 1-5 was performed using linear regression analysis, a method equivalent to the analysis of covariance (ANCOVA). For other analyses, paired $t$ test [e.g., total HCN1 (AU) along lines a, b, c; see Fig. $1 H, l]$ or Wilcoxon signed rank test (for Western blot analyses, comparing experimentally treated and corresponding vehicle-treated control groups, set to $100 \%$; e.g., Fig. $1 K)$ were applied. Statistical analyses were performed with Prism software (Prism 6, GraphPad). Data are presented as mean \pm standard error of the mean.

\section{Results}

\section{E2 promotes the distal dendritic enrichment of HCN1 in CA1 pyramidal cells}

We initially studied effects of E2 on HCN1 distribution in CA1 using combined entorhino-hippocampal slice cul- tures, prepared from early postnatal (P5) rats and cultivated for a total of $11 \mathrm{~d}$ (DIV11). Experimental treatment (DIV5-DIV11) specifically comprised the time span during which the HCN1 pattern in CA1 is developmentally forming (Brewster et al., 2007; Shin and Chetkovich, 2007). As shown in Fig. 1, the characteristic in vivo pattern of $\mathrm{HCN} 1$ distribution in CA1 is reproduced in vitro at DIV11 (compare Fig. $1 A, B$ ): HCN1 immunohistochemistry increases from proximal to distal, resulting in an enrichment at the hippocampal fissure (indicated by asterisks). No pattern was observed if the primary antibody was omitted (Fig. $1 C, D)$. Quantitative analysis along proximal-distal lines in vitro (Fig. $1 E$ ) revealed that, under control conditions, 57 $\pm 2 \%$ of the HCN1 immunosignal located to segments 4 and 5 , which roughly comprise stratum lacunosummoleculare $(\mathrm{s} / \mathrm{m})$, with the majority $(31 \pm 1 \%)$ localizing to segment 5 , which borders the hippocampal fissure (Fig. $1 F)$. Supplementing the culture medium with E2 $\left(10^{-7} \mathrm{M}\right)$ augmented the proportion of HCN1 channels localizing to segments 4 and 5 , which was particularly evident in segment 5 (34 $\pm 1 \%, n=21$; Wilcoxon matched pairs signed rank test: $p=0.02$; Figs. $1 F, H, I$. Correspondingly, the proportion of channels localizing to segments $1-3$, comprising stratum radiatum (sr), decreased significantly (E2: $39 \pm 2 \%$ vs. Ctl: $43 \pm 2 \%, n=21$; Wilcoxon matched pairs signed rank test: $p=0.04$ ). Consequently, the proximal-distal HCN1 gradient, denoted by the slope from segment $1-5$, was significantly increased in the presence of E2 (E2: $6.26 \pm 0.35$ vs. Ctl: $5.04 \pm 0.36, n=21$; linear regression analysis: $F=5.9, D F n=1, D F d=206, p=$ $0.016)$, showing that $E 2$ had promoted the developmental enrichment of $\mathrm{HCN} 1$ in the CA1 distal dendritic segment (Fig. 1G). These initial findings were reliably reproduced in all follow-up experiments, in which an E2-treated group of cultures was included (e.g., Figs. $2 C, D$ ), resulting in a total of 52 cultures that were analyzed for the effect of E2. Among these 52 cultures, no sex bias was observed [in segment 5 , female: $36 \pm 2 \%$ (E2) vs. $31 \pm 1 \%$ (Ctl), $n=$ 27; Wilcoxon matched pairs signed rank test: $p=0.004$; male: $35 \pm 1 \%$ (E2) vs. $31 \pm 1 \%$ (Ctl), $n=25$; Wilcoxon matched pairs signed rank test: $p=0.02$ ]. Therefore, the sex of the animals from which the cultures were generated 
A

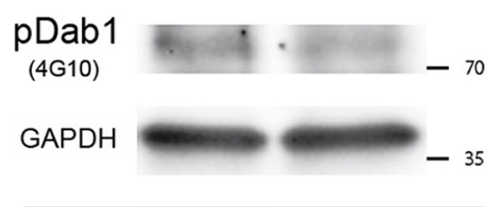

Dab1

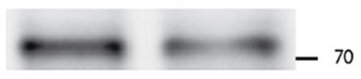

GAPDH

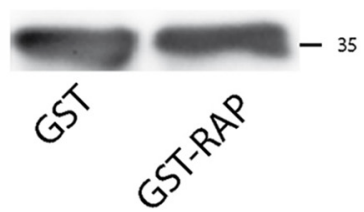

C

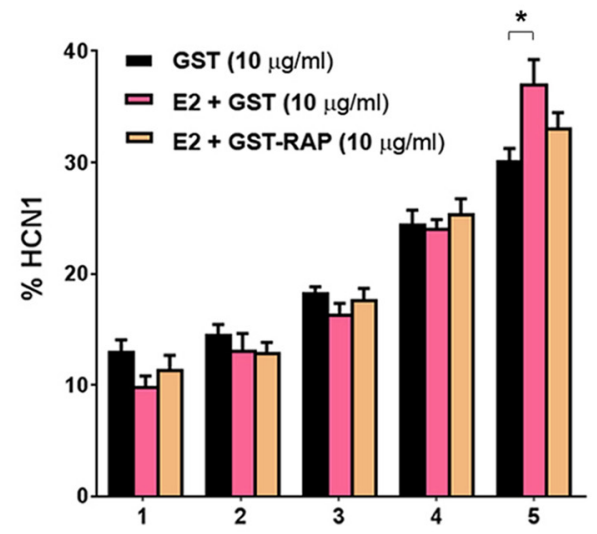

B

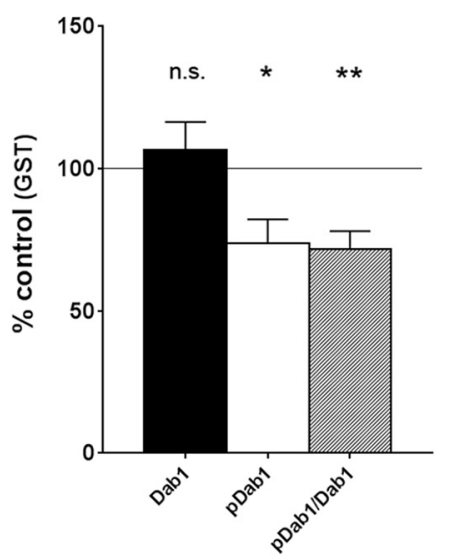

D
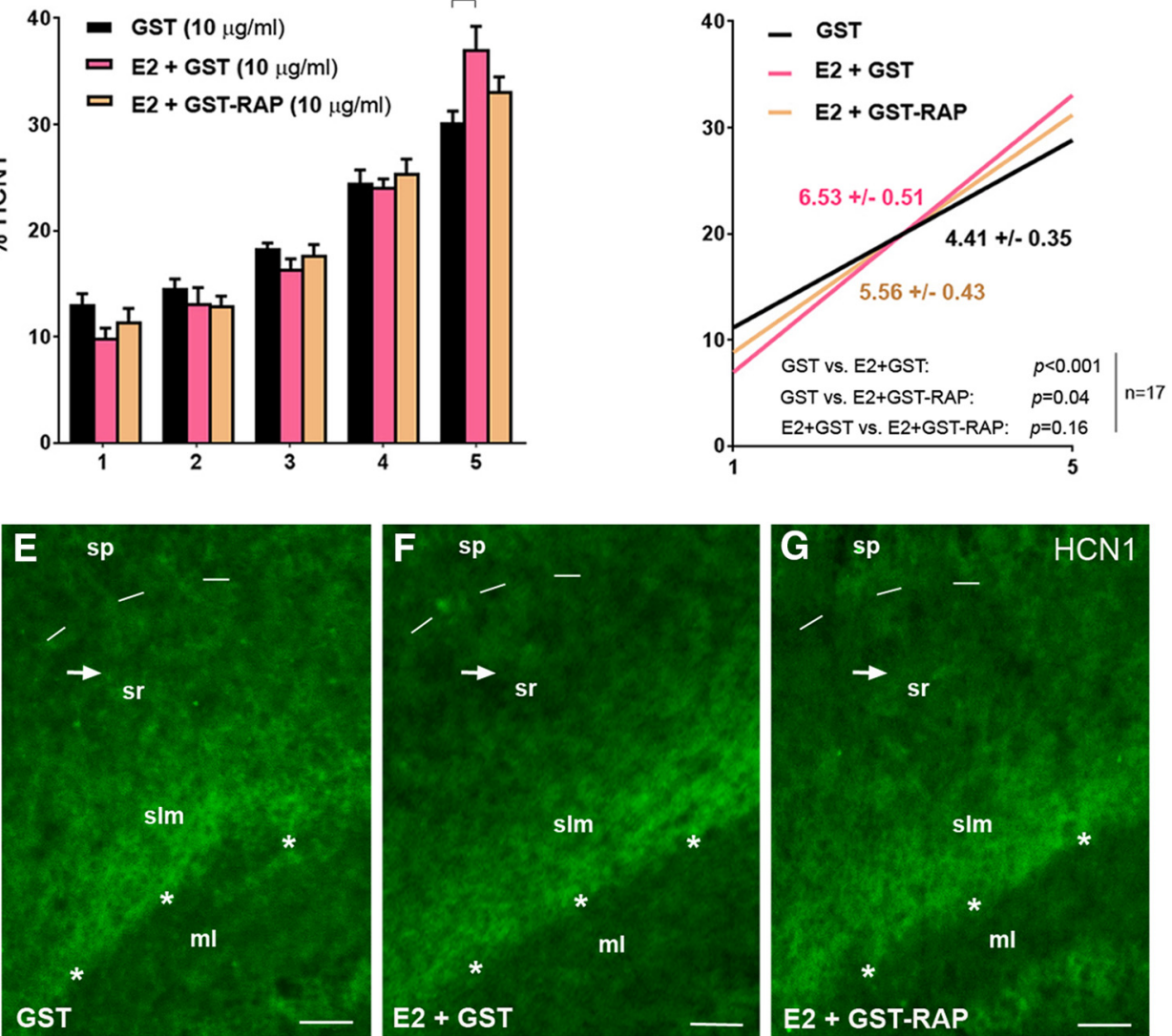

Figure 2. Coapplication of GST-RAP does not prevent the E2-induced distal dendritic HCN1 enrichment in vitro. $\boldsymbol{A}$, Western blots showing phosphorylated Dab1 (pDab1, upper bands, detected by anti-phosphotyrosine antibody 4G10) and total Dab1 (lower bands) in "paired" slice cultures that were treated for $24 \mathrm{~h}$ (DIV10-11) with either GST-RAP or GST (10 $\mu \mathrm{g} / \mathrm{ml}$ each) and were exposed to Reelin-conditioned medium for 30 min before harvesting. GAPDH was used for loading control. B, Quantitative analysis of Dab1 and pDab1 levels (relative to GAPDH) revealed that Reelin-induced pDab1 was reduced in the GST-RAP-treated slices, while total Dab1 was not significantly different compared to the GST-treated controls. Thus, pDab1/Dab1 was reduced to $72 \% \pm 6 \%$ of control levels after 24-h GST-RAP treatment $p$ $<0.01 ; n=15)$. C, $\boldsymbol{D}$, E2 (+GST)-treatment (pink) of cultures for 6 d (DIV5-11) caused a significant HCN1 accumulation in segment 5 (C) and a significantly increased slope $(\boldsymbol{D})$ compared with controls (GST, black) that was not efficiently reduced, if GST-RAP (10 $\mu \mathrm{g} / \mathrm{ml})$ was coapplied (orange; $n=17$, each group). $\boldsymbol{E}-\mathbf{G}$, Representative photographs from a culture "triple," of which one culture served as a vehicle (GST)-treated control $(\boldsymbol{E})$, while the others were treated with either E2 + GST $(\boldsymbol{F})$ or E2 + GST-RAP $(\boldsymbol{G})$. Note that HCN1 is accumulated at the hippocampal fissure (asterisks) at all conditions, but if E2 was present $(\boldsymbol{F}, \boldsymbol{G})$, less HCN1 immunosignal is visible in stratum radiatum (sr, arrows), indicating (relative) HCN1 enrichment in stratum lacunosum-moleculare (slm). Scale bars: $80 \mu m$ (E-G). Dashed lines demarcate the border of stratum pyramidale (sp). $\mathrm{ml}$, molecular layer. 
was not further considered in subsequent experiments. Differences between experimental groups were not evident for total HCN1 signal intensity in CA1 (E2: $7078 \pm$ 767 vs. Ctl: $6570 \pm 789 \mathrm{AU}, n=21$; paired $t$ test: $p=0.6$; Fig. 1/) and HCN1 protein levels in the whole cultures (E2: $103 \pm 18 \%$ relative to controls, $n=9$; Wilcoxon signed rank test: $p=0.6$; Fig. $1 J, K)$, suggesting that it is a distal dendritic shift of the HCN1 channels, involving altered channel trafficking, rather than altered HCN1 expression, that causes the increased HCN1 immunosignal in the distal segments.

\section{E2-induced distal enrichment of HCN1 in CA1 does not involve Reelin signaling}

We next questioned whether the effect of E2 on HCN1 distribution in CA1 is mediated by Reelin. For this purpose, we used the LRP inhibitor GST-RAP at concentrations $(10 \mu \mathrm{g} / \mathrm{ml})$ that had previously been shown to reduce Reelin signaling in neuron cultures (Groc et al., 2007) and reduced Reelin-induced Dab1-phosphorylation (pDab1/ Dab1) to $72 \% \pm 6 \%$ of control levels (GST) in slice cultures, which were preincubated with GST-RAP for $24 \mathrm{~h}$ (DIV10-DIV11) and then exposed to Reelin $(n=15$; Wilcoxon signed rank test: $p=0.001$; Fig. $2 A, B$ ). However, co-applying E2 and GST-RAP for a 6-d treatment period (DIV5-DIV11, as above) did not efficiently block the distal enrichment of HCN1 that was induced in CA1, if E2 was supplemented only with GST [segment 5: E2 + GST: $37 \%$ $\pm 2 \%$ vs. GST alone: $30 \% \pm 1 \%$; Friedman test: $p=0.07$; Dunn's multiple comparisons test: $p<0.05$ (E2 + GST vs. GST); slopes: E2 + GST: $6.53 \pm 0.52$ vs. GST: $4.41 \pm$ $0.35, n=17$; linear regression analysis: $F=11.5, D F n=$ $1, D F d=166, p<0.001$; Fig. 2C-G]. In fact, coapplication of E2 and GST-RAP still resulted in a significantly steeper slope relative to the controls (E2 + GSTRAP: $5.56 \pm 0.43$ vs. GST: $4.41 \pm 0.35, n=17$; linear regression analysis: $F=4.5, D F n=1, D F d=166, p=$ 0.04; Fig. $2 C-G$ ), whereas no significant difference was evident if E2 + GST and E2 + GST-RAP slopes were compared (linear regression analysis: $F=2.0, D F n=1$, $D F d=166, p=0.16$; Fig. 2C-G). We therefore reasoned that the GST-RAP-induced inhibition of Reelin signaling was either not sufficient to suppress the E2-induced increase of HCN1 in distal CA1 or, more generally, that Reelin is not required for the distal HCN1 enrichment in our experimental setting.

To address the latter possibility, GST-RAP (or GST) was applied to the culture medium of P5 cultures without co-applying E2 for $6 \mathrm{~d}(10 \mu \mathrm{g} / \mathrm{ml}$, DIV5-DIV11; Fig. 3A,B) or $48 \mathrm{~h}(50 \mu \mathrm{g} / \mathrm{ml}$, DIV8-DIV10; Fig. $3 C-F)$, thus reproducing the experimental conditions of Kupferman et al. (2014). However, none of these treatments altered the somatodendritic gradient of HCN1. Even the high concentrations of GST-RAP $(50 \mu \mathrm{g} / \mathrm{ml})$ did not prevent the accumulation of HCN1 at the hippocampal fissure [slopes: $5.15 \pm 0.36$ (GST-RAP) vs. $4.48 \pm 0.42$ (GST), $n=17$; linear regression analysis: $F=1.5, D F n=1, D F d=166$, $p=0.22$; Fig. $3 D$ ]. Similarly, Reelin-binding antibody CR-50 $(2 \mu \mathrm{g} / \mathrm{ml}$ ), applied to the cultures for 6 d (DIV5DIV11), did not affect HCN1 distribution in CA1 [slopes:
$6.01 \pm 0.28$ (CR-50) vs. $5.90 \pm 0.28(\mathrm{lgG}), n=17$; linear regression analysis: $F=0.09, D F n=1, D F d=166, p=$ 0.77 ; Fig. $3 G, H]$. None of these treatments altered total $\mathrm{HCN} 1$ expression in CA1, as total integrated densities were not significantly different from controls in the experimental groups [GST-RAP $(10 \mu \mathrm{g} / \mathrm{ml}): 1859 \pm 197 \mathrm{vs}$. GST $(10 \mu \mathrm{g} / \mathrm{ml}): 1620 \pm 183 \mathrm{AU}$; GST-RAP $(50 \mu \mathrm{g} / \mathrm{ml}): 2502 \pm$ 282 vs. GST ( $50 \mu \mathrm{g} / \mathrm{ml}): 2182 \pm 244$ AU; CR-50: $2615 \pm$ 366 vs. IgG: $2905 \pm 258 \mathrm{AU}$; paired $t$ tests: $p=0.24,0.32$ and 0.50 , respectively].

Because different experimental conditions could have caused the discrepancies with Kupferman et al. (2014), we further examined the distribution of HCN1 in 7-8month-old tamoxifen-inducible reelin-knockout mice, in which the reelin gene was eliminated at 2 months of age (Reelin cKO; Lane-Donovan et al., 2015). In these mice, the hippocampus had a normal cytoarchitecture (e.g., cellular layers were distinct and the hippocampal fissure was clearly recognizable), but Reelin-expressing cells were completely absent (compare Fig. $4 A, C$ ). Nevertheless, HCN1 distribution in CA1 was not different from that in control mice (WT; compare Fig. 4B,D), and no effect of Reelin deficiency on the distal dendritic enrichment of HCN1 was detectable [slopes: $9.61 \pm 1.15$ (WT) vs. 9.52 \pm 1.12 (Reelin $\mathrm{CKO}$ ), $n=5$ each; linear regression analysis: $F=0.003, D F n=1, D F d=46, p=0.95$; Fig. $4 E, F$. Furthermore, the distribution of TRIP8b, an HCN channel auxiliary subunit that is important for HCN1 subcellular trafficking (Lewis et al., 2011; Piskorowski et al., 2011; Wilkars et al., 2012), was virtually unaffected by Reelin deficiency (Fig. 4G,H; but see Kupferman et al., 2014). Taken together, these findings argue against a critical role of Reelin in the regulation of HCN1 distribution in CA1.

\section{E2-induced distal enrichment of HCN1 in CA1 is mediated via GPER1}

We next wanted to understand how E2 effects on HCN1 distribution in CA1 are mediated, if Reelin is not involved. For this purpose, selective agonists of the estrogen receptors $\mathrm{ER} \alpha$ (PPT, Fig. 5A,B), ER $\beta$ (DPN, Fig. 5C,D), and G protein-coupled GPER1 (G1, Fig. 5E,F) were applied for $6 \mathrm{~d}$ (as above) to the culture medium, and effects on HCN1 distribution in CA1 were determined. Only treatment with $\mathrm{G} 1$ caused a significant shift of $\mathrm{HCN} 1$ toward the distal segments and a significant enhancement of the slope (G1: $6.03 \pm 0.27$ vs. Ctl: $4.50 \pm 0.29, n=21$, linear regression analysis: $F=14.5, D F n=1, D F d=206, p<$ 0.001 , Fig. $5 F$ ), whereas none of the other agonists had an effect (PPT: $5.36 \pm 0.39$ vs. Ctl: $4.81 \pm 0.42, n=16, F=$ $0.9, D F n=1, D F d=156, p=0.34$, Fig. 5B; DPN: $5.16 \pm$ 0.32 vs. Ctl: $5.24 \pm 0.40, n=20, F=0.02, D F n=1, D F d$ $=196, p=0.88$, Fig. $5 D$ ), suggesting that E2 effects are mediated via GPER1. To control for this scenario, we co-applied E2 (100 nM) with the GPER1 antagonist G36 (20 nM; Figs. 5G,H) during the 6-d treatment period and found that the E2-induced distal dendritic enrichment was abolished in the presence of G36, as evident from the bar charts [e.g., segment 5: $37 \pm 1 \%$ (E2) vs. $32 \pm 1 \%$ (Ctl) and $33 \pm 2 \%$ (E2 + G36), $n=14$ each; Friedman test: $p=$ 0.004; Dunn's multiple comparisons test: $p<0.05$ (E2 vs. 
A

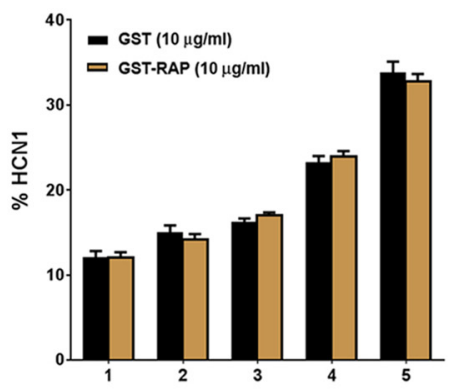

B
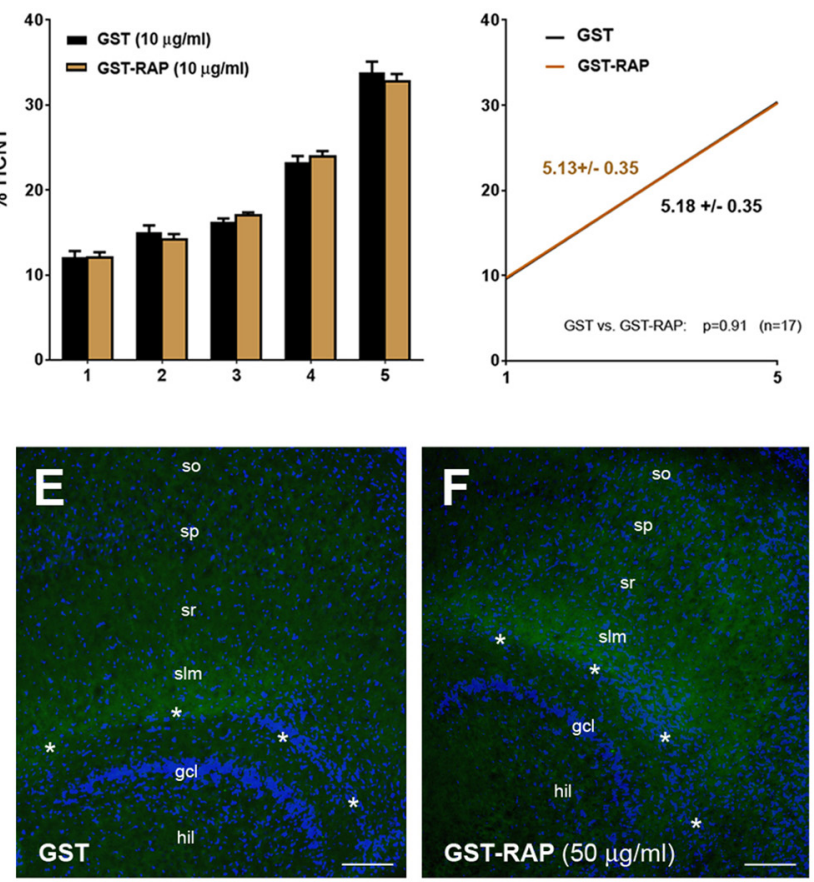

C

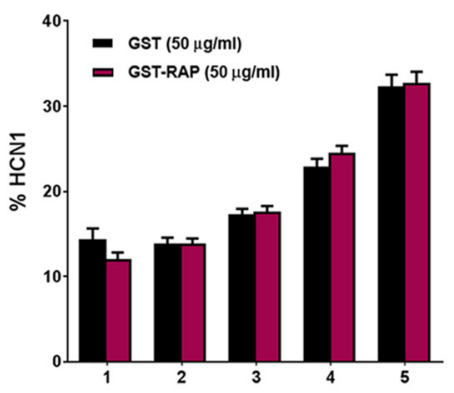

G

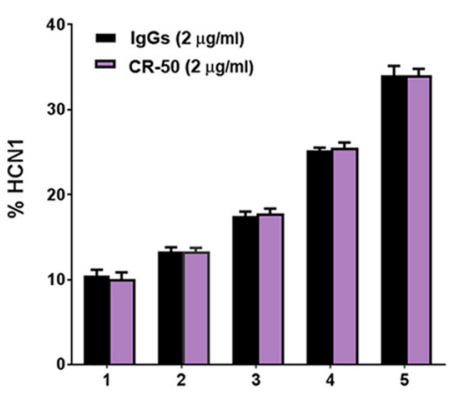

D

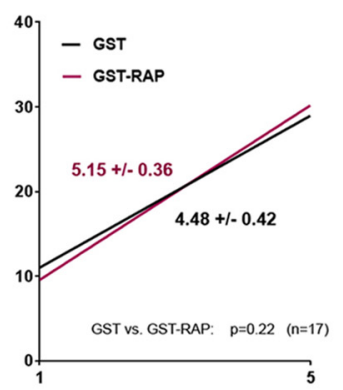

H

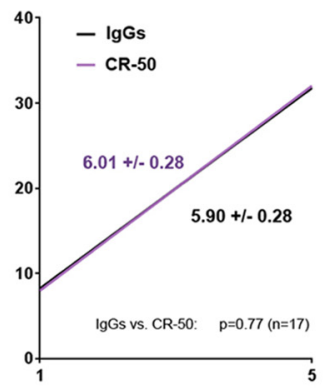

Figure 3. Reelin is not required for HCN1 distal dendritic enrichment in CA1 in vitro. $\boldsymbol{A}-\boldsymbol{D}$, To test whether Reelin is generally required for the distal dendritic enrichment of HCN1 in CA1 in vitro, organotypic slice cultures were treated with GST or GST-RAP for 6 days $(10 \mu \mathrm{g} / \mathrm{ml}$, DIV5-11, $n=17 ; \boldsymbol{A}, \boldsymbol{B})$ or in higher concentration for $48 \mathrm{~h}(50 \mu \mathrm{g} / \mathrm{ml}$, DIV8-10, $n=17 ; \boldsymbol{C}, \boldsymbol{D})$. None of these treatments prevented HCN1 enrichment in distal CA1. $\boldsymbol{E}, \boldsymbol{F}$, Photographs show HCN1 distribution in slice cultures treated for $48 \mathrm{~h}$ with either GST $(50 \mu \mathrm{g} / \mathrm{ml} ; \boldsymbol{E})$ or GST-RAP $(50 \mu \mathrm{g} / \mathrm{ml} ; \boldsymbol{F})$, demonstrating unaltered HCN1 enrichment in distal CA1. Sections have been immunostained for HCN1 (green) and counterstained with DAPI (blue). G, H, Supplementing Reelin-blocking CR-50 antibodies (2 $\mu$ g/ml, DIV5-11, $n$ $=17$ ) in the culture medium did also not alter HCN1 distribution in CA1. Note: none of the treatments above altered total HCN1 expression in CA1 (see Results). Scale bars $(\boldsymbol{E}, \boldsymbol{F}): 100 \mu \mathrm{m}$. hil, hilus; gcl, granule cell layer; slm, stratum lacunosum-moleculare; sp, stratum pyramidale; so, stratum oriens; sr, stratum radiatum. Asterisks indicate the hippocampal fissure.

$\mathrm{Ctl}), p<0.01$ (E2 vs. $\mathrm{E} 2+\mathrm{G} 36), p>0.05$ (Ctl vs. E2 + G36), Fig. 5G] and the slopes [5.62 \pm 0.37 (Ctl) vs. $7.48 \pm$ 0.35 (E2) and $5.77 \pm 0.32$ (E2 + G36); linear regression analyses: $F=13.4, D F n=1, D F d=136, p<0.001$ (E2 vs. $C t$ ) $; F=16.8, D F n=2, D F d=159, p<0.001$ (E2 vs. $\mathrm{E} 2+\mathrm{G} 36) ; F=0.1, D F n=1, D F d=136, p=0.76$ (Ctl v. E2 + G36), Fig. 5H]. Further, GPER1 immunohistochemistry suggests that this receptor is in a suitable position to mediate site-specific E2 effects in CA1, as both in P16 rats and in age-equivalent cultures, GPER1 expression is high in the CA1 dendritic field, but very low in other areas, such as the hilus (Figs. 5/,J; see also Waters et al., 2015). Notably, G1 treatment did not significantly alter total HCN1 or GPER1 protein levels within the cultures [relative to control: $103 \pm 24 \%$ (HCN1), $91 \pm 4 \%$ (GPER1), $n=6$ each; Wilcoxon matched pairs signed rank test: $p=0.9$ and $p=0.09$, respectively; Fig. $5 K, L]$.

\section{Distal dendritic enrichment of HCN1 is not affected by the female estrous cycle}

The organotypic slice culture model is most suitable to address developmental processes, including the maturation of the HCN1 distribution pattern, which is evolving during the first postnatal weeks (Brewster et al., 2007; Shin and Chetkovich, 2007). However, a specific feature of estrogens is their fluctuation during the female estrous cycle, and several cycle-dependent effects on hippocampal plasticity have been described (Woolley and McEwen, 1992; Scharfman and MacLusky, 2006). We therefore wanted to know whether the localization of the HCN1 channels in CA1 changes during the estrous cycle. For this purpose, HCN1 distribution in CA1 was analyzed in female mice that were either in proestrus (high serum E2; Fig. 6C, upper panel) or diestrus (low serum E2, Fig. 6C, lower panel). Age-equivalent male mice $(n=6)$ were examined for comparison. The analysis revealed no significant differences between the female cycle stages [slopes: $10.5 \pm 1.0$ (proestrus) vs. $11.6 \pm 1.1$ (diestrus), $n$ $=6$ each; linear regression analysis: $F=0.5, D F n=1$, $D F d=56, p=0.47$; Fig. $6 A, B]$. When males and females were compared, differences relative to proestrus females became apparent in some segments (segments 2 and 3; Fig. 6A). However, when the slopes were considered, the HCN1 gradient in males proved not to be significantly different from the gradients in proestrus or diestrus females (male slope: $12.0 \pm 1.2, n=6$; linear regression analysis: $F=0.9, D F n=1, D F d=56, p=0.35$ relative to proestrus; $F=0.07, D F n=1, D F d=56, p=0.8$ relative to diestrus; Fig. $6 B$ ). This would argue against a role of 

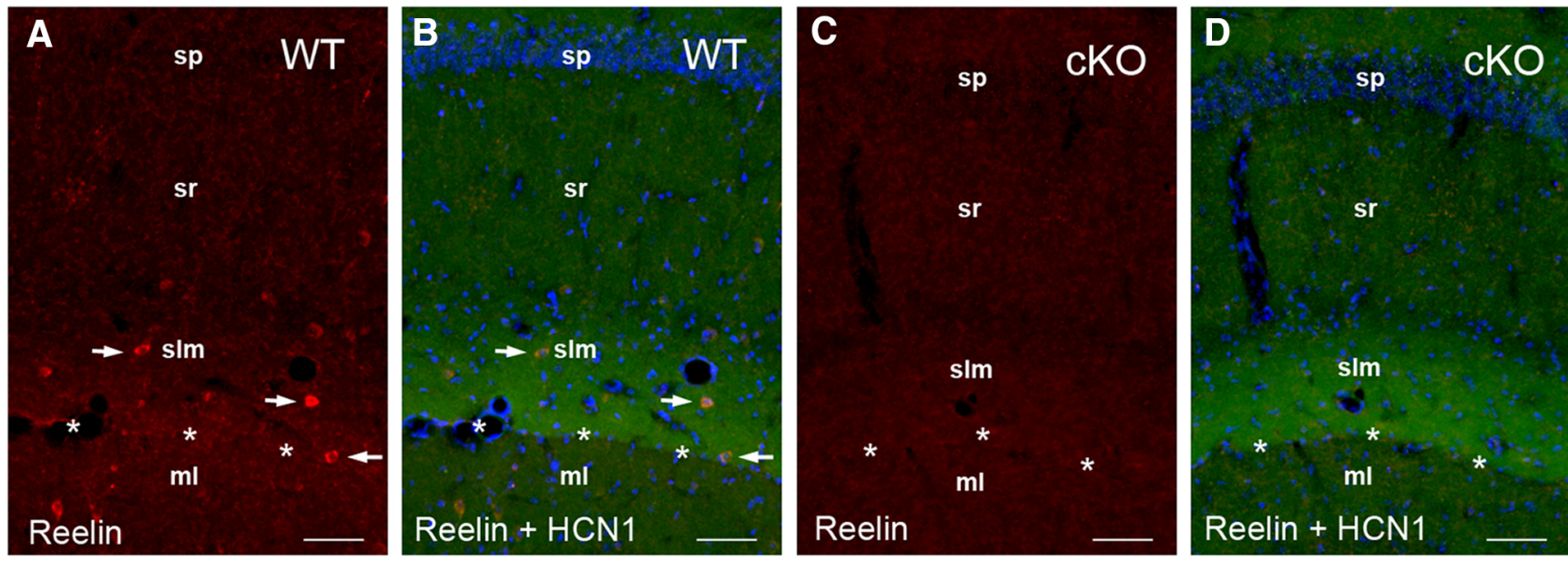

E

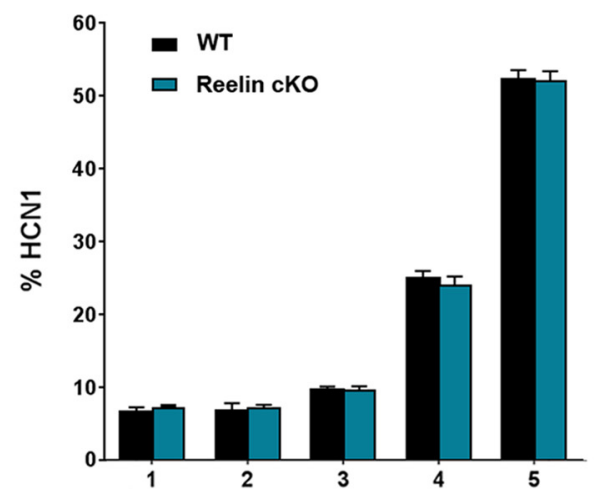

$\mathbf{F}$

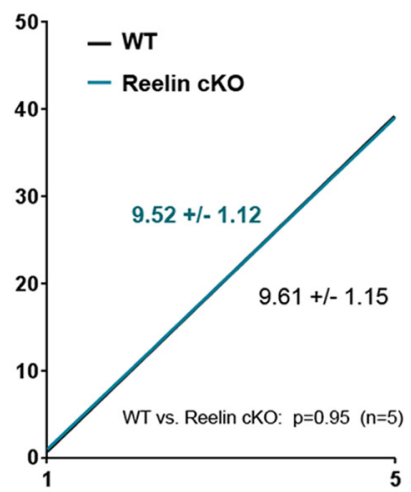

G
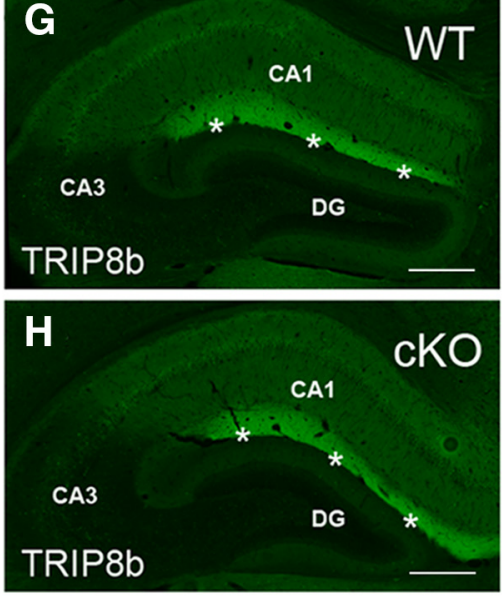

Figure 4. Reelin is not required for HCN1 distal dendritic enrichment in CA1 in vivo. $\boldsymbol{A}-\boldsymbol{D}$, Photographs show CA1 in adult mice (7-8 months), in which reelin was deleted at 2 months of age via tamoxifen induction (cKO; $\boldsymbol{C}, \boldsymbol{D})$, or the corresponding wild types (WT; $\boldsymbol{A}, \boldsymbol{B})$. Sections have been immunostained for Reelin (red; $\boldsymbol{A}-\boldsymbol{D})$ and HCN1 (green; $\boldsymbol{B}$ and $\boldsymbol{D}$ ). Note that Reelin-expressing cells, which are prominent in stratum lacunosum-moleculare (s/m) of the WT (see arrows in $\boldsymbol{A}$ and $\boldsymbol{B}$ ), are completely absent in the cKO-mice (C), $\boldsymbol{D})$. This did not prevent the accumulation of $\mathrm{HCN} 1$ in distal CA1 near the hippocampal fissure (indicated by asterisks). $\boldsymbol{E}$, $\boldsymbol{F}$, Quantification revealed a virtually identical somatodendritic HCN1 gradient in Reelin cKO compared with WT mice, both within individual segments ( $\boldsymbol{E}$; Mann-Whitney test: $p>0.05$ for each segment; $n=5$ each group) and if the slopes were compared ( $\boldsymbol{F}$; linear regression analysis: $p=0.95)$. $\boldsymbol{G}, \boldsymbol{H}$, Similarly, TRIP8b enrichment in distal CA1 was not altered in Reelin-deficient mice $(\boldsymbol{H})$ compared to WT $(\boldsymbol{G})$. Scale bars: $80 \mu \mathrm{m}(\boldsymbol{A}-\boldsymbol{D}), 400 \mu \mathrm{m}(\boldsymbol{G}, \boldsymbol{H})$. CA, cornu ammonis; DG, dentate gyrus; ml, molecular layer; sp, stratum pyramidale; sr, stratum radiatum.

gonadally synthesized estradiol. However, because under physiologic conditions hippocampus-derived E2 is generated in both male and female rodent hippocampus (Vierk et al., 2014; Hojo and Kawato, 2018), hippocampal aromatase could play a regulatory role (Prange-Kiel et al., 2003; Hojo et al., 2004). Indeed, as indicated by immunohistochemistry, aromatase expression is substantial in the dendritic area of CA1 (Fig. 6D) and most prominent in stratum lacunosum-moleculare [188 $\pm 18 \%$, compared to expression in stratum radiatum, $n=6$ (3 proestrus, 3 estrus); Wilcoxon signed rank test: $p=0.03$; Fig. $6 E$ ].

\section{Discussion}

The apical dendrites of CA1 pyramidal cells integrate excitatory synaptic input from mainly two sources: from CA3 via the Schaffer collaterals, which terminate proximally in stratum radiatum, and from the entorhinal cortex via the perforant path, which forms synapses distally in stratum lacunosum-moleculare. To achieve proper integration, different sets of ion channels localize to the proximal and distal dendritic portions, enabling these compartments to shape the computational and storage capabilities of neurons according to functional requirements (Magee and Johnston, 2005; Nusser, 2012). Little is known yet about the mechanisms that direct the ion channels to their specific dendritic compartments. Here we provide evidence that $17 \beta$-estradiol (E2), acting through the G protein-coupled estrogen receptor GPER1, is a regulating factor, as it promotes the enrichment of HCN1 channels within the distal segment of CA1 pyramidal cell apical dendrites. We could not verify, however, the previously suggested role of Reelin for the establishment and preservation of the somatodendritic gradient of HCN1 channels in CA1 (Kupferman et al., 2014). 
A

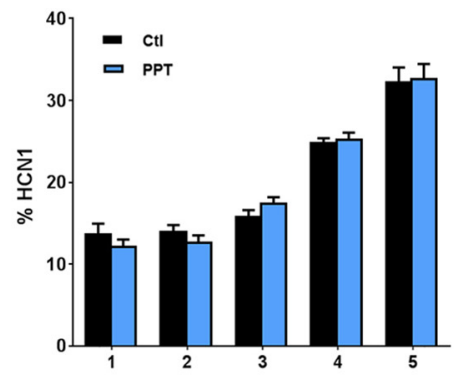

E

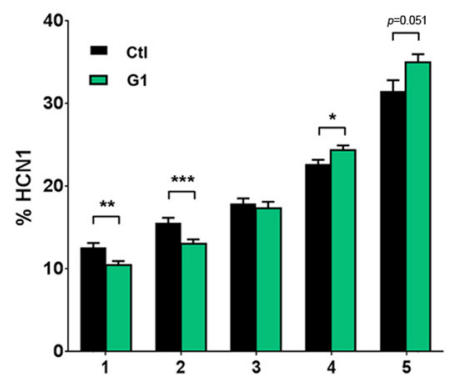

B

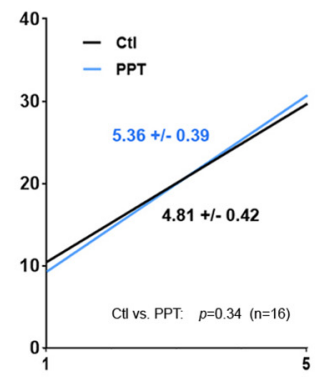

F

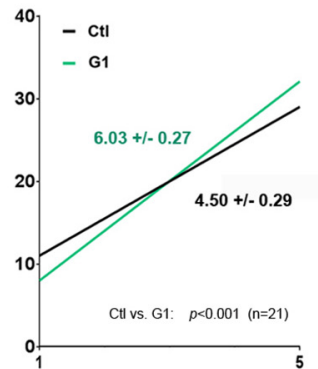

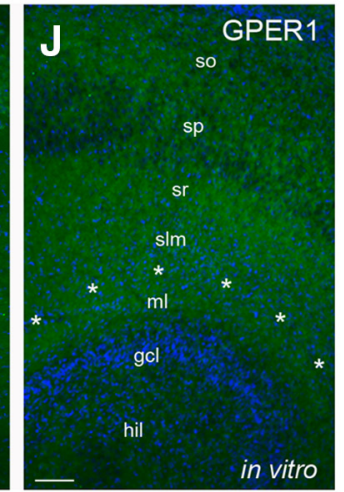

C

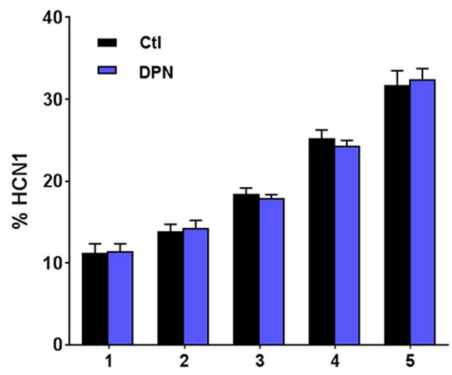

G

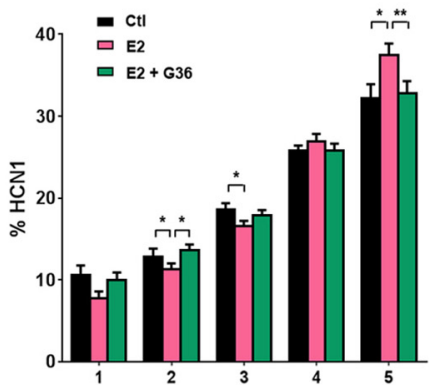

K

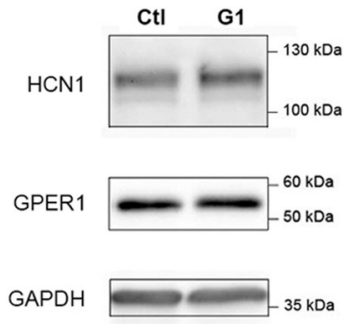

D

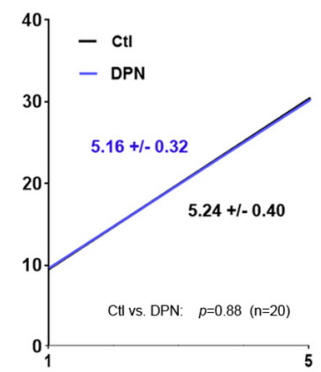

H

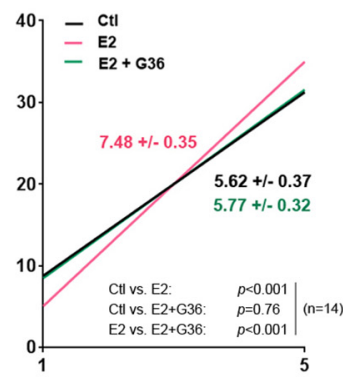

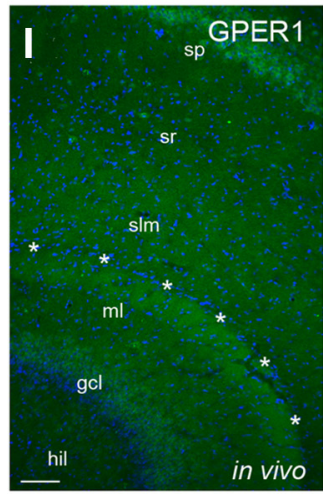

L

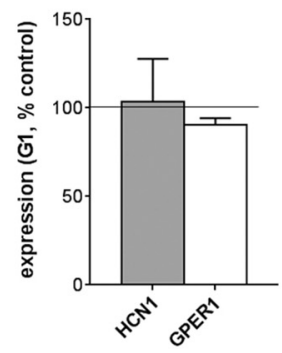

Figure 5. E2 effects on HCN1 distribution in CA1 are mediated by GPER1. $\boldsymbol{A}-\boldsymbol{F}$, Application of agonists for estrogen receptors ER $\alpha$ (PPT, $100 \mathrm{nM}, n=16 ; \boldsymbol{A}, \boldsymbol{B}), \mathrm{ER} \beta$ (DPN, $100 \mathrm{nM}, n=20 ; \boldsymbol{C}, \boldsymbol{D})$, or GPER1 (G1, $20 \mathrm{nM}, n=21 ; \boldsymbol{E}, \boldsymbol{F}$ ) to the culture medium for $6 \mathrm{~d}$ (DIV5-11) resulted only for G1 in a significant enhancement of HCN1 distal dendritic expression (E, $\boldsymbol{F}$ ). No effect was observed with PPT or DPN. G, $\boldsymbol{H}$, Coapplication of E2 (100 nM) with the GPER1 antagonist G36 $(20 \mathrm{nM}, n=14)$ abolished the E2-mediated HCN1 enrichment in distal CA1, suggesting that the G protein-coupled receptor GPER1 is mediating the E2 effect. I, J, Photographs show CA1 in sections from a P16 rat (in vivo, $I$ ) and from an age-equivalent slice culture (in vitro; P5, DIV11; J). Sections have been immunostained for GPER1 (green) and counterstained with DAPI (blue). Note: both in vivo and in vitro, robust GPER1-immunosignal is detectable in the areas surrounding the hippocampal fissure (asterisks) and in the CA1 dendritic field, but signal is almost absent in the hilus (hil). $\boldsymbol{K}$, Representative Western blots showing HCN1 (upper lane), GPER1 (middle lane), and GAPDH bands (lower lane, used as loading control) in tissue from slice cultures treated for $6 \mathrm{~d}$ (DIV5-11) with either G1 or vehicle (CtI). $\boldsymbol{L}$, Quantification did not reveal any effect of G1 treatment on either HCN1 (103\% $\pm 24 \%, p=0.9, n=6)$ or GPER1 $(91 \% \pm 4 \%, p=0.09, n=6)$ protein expression in the cultures. Scale bars $(\boldsymbol{I}, \boldsymbol{J}): 100 \mu \mathrm{m}$. gcl, granule cell layer; slm, stratum lacunosum-moleculare; sp, stratum pyramidale; so, stratum oriens; sr, stratum radiatum.

The findings by Kupferman et al. (2014), suggesting that disrupting Reelin signaling causes mislocalization of HCN1 and its auxiliary subunit TRIP8b in hippocampal and neocortical pyramidal neurons, were intriguing, because they provided for the first time a hint at a noncell-autonomous factor that regulates $\mathrm{HCN}$ channel distribution. The primary source of Reelin are Cajal-Retzius (CR) cells, which are considered pioneer neurons required for cortical lamination (D'Arcangelo et al., 1995; Ogawa et al., 1995; Tissir and Goffinet, 2003; Förster et al., 2006). Most CR cells die early during development. However, in hippocampus, a substantial number of them survive and continue to produce Reelin throughout maturity (Anstötz et al., 2016). These cells, bordering the hippocampal fissure (see Fig. $4 A$ ), are generally well positioned to promote HCN1 trafficking toward the distal dendritic 
A

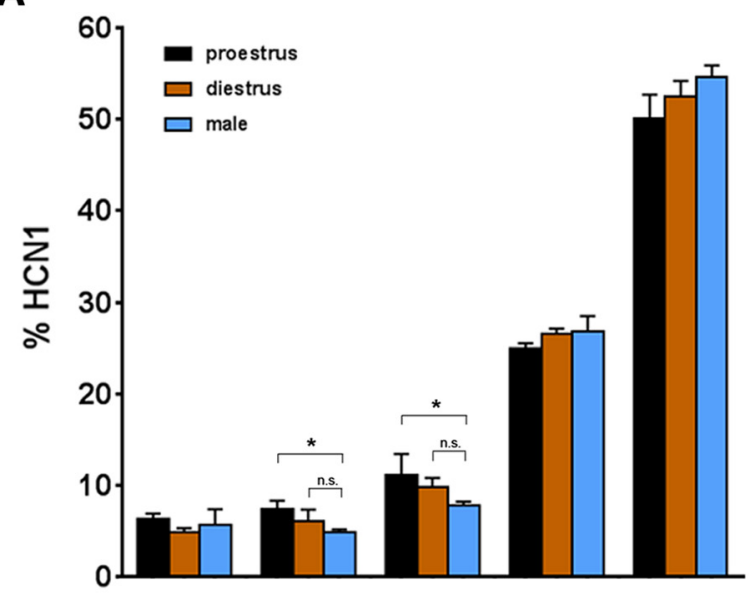

B

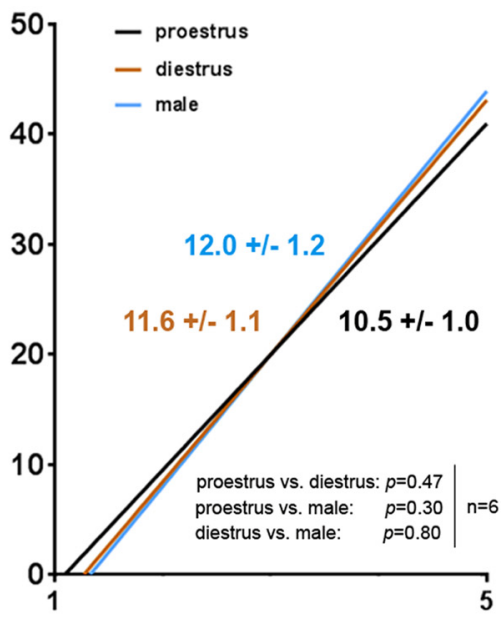

E
C
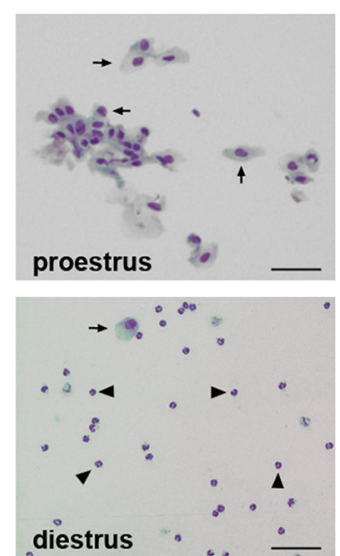

D

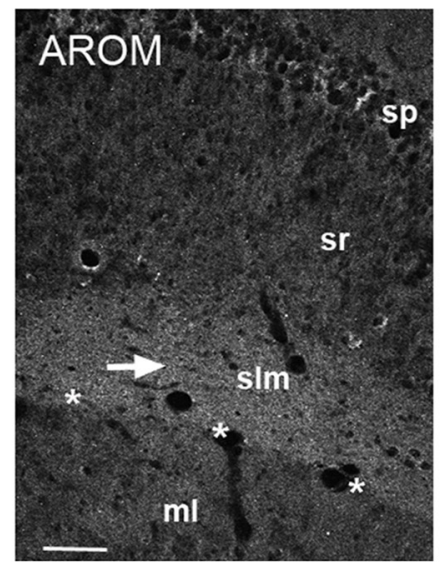

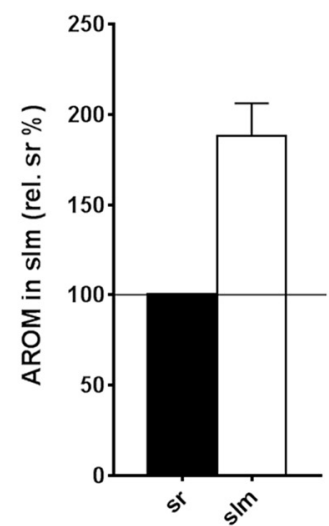

Figure 6. Effects of the female estrous cycle. $\boldsymbol{A}, \boldsymbol{B}$, Quantitative analysis of CA1 HCN1 distribution in sections from female mice, which were in stages of the estrous cycle with the most discrepant E2 serum levels (black: high E2 in proestrus, orange: low E2 in diestrus; $n=6$ each), and from age-equivalent male mice (blue, $n=6$ ) for comparison. No significant differences between females in differing cycle stages were evident within individual segments $(\boldsymbol{A})$ or between the slopes $(\boldsymbol{B})$. When males and females were compared, a trend toward reduced $\mathrm{HCN} 1$ in stratum radiatum was apparent in the males (relative to proestrus females) in individual segments [e.g., in segment 2: Kruskal-Wallis test: $p=0.04$; Dunn's multiple comparisons test: $p<0.05$ (male vs. proestrus), $\boldsymbol{A}$ ], but this trend did not prove to be significant, if linear regression analysis was applied $(\boldsymbol{B})$. $\boldsymbol{C}$, Representative cytology showing vaginal smears deriving either from a female mouse in proestrus (upper panel) or a mouse in diestrus (lower panel). Note that in proestrus almost exclusively nucleated epithelial cells (arrows) are observed in the vaginal smear. In diestrus, however, leukocytes (arrowheads) predominate, whereas nucleated epithelial cells are rarely seen (Byers et al., 2012). D, Confocal microscopy illustrating aromatase (AROM) expression in the CA1 dendritic field, specifically in stratum lacunosum-moleculare (slm, arrow). Because neuronal aromatase activity is inversely related to serum E2 levels, due to its regulation by the hypothalamic-pituitary axis (Prange-Kiel et al., 2008; Kato et al., 2013), it could balance the varying levels of peripheral hormones during the estrous cycle. Note: to control for specificity, aromatase immunohistochemistry was performed with three different antibodies directed against three different antigenic regions (see Methods for details). All revealed virtually identical staining patterns, which were not observed if primary antibodies were omitted. $\boldsymbol{E}$, Quantification of relative aromatase expression indicates a significantly higher expression in $\operatorname{sim}(188 \% \pm 18 \%, p=0.03, n=6)$ compared to stratum radiatum (sr). Scale bars: $50 \mu \mathrm{m}(\boldsymbol{C}), 80 \mu \mathrm{m}(\boldsymbol{D})$. sp, stratum pyramidale; ml, molecular layer. Asterisks indicate the hippocampal fissure.

compartment of CA1 pyramidal cells. Neocortical CR cells, in contrast, vanish almost completely long before maturity (Del Río et al., 1995; Anstötz et al., 2014), rendering them an unlikely source of adult Reelin. The loss of neocortical CR cells could here be compensated by cortical interneurons, which begin to express Reelin with maturation (Alcántara et al., 1998; Pesold et al., 1998; Pohlkamp et al., 2014).
Because E2 promotes the expression of Reelin (Bender et al., 2010), we hypothesized that E2 mediates its effects on HCN1 distribution via Reelin. However, our data do not support this hypothesis, because inhibiting Reelin signaling using GST-RAP in concentrations that lower Dab1 phosphorylation to $72 \%$ of controls (Fig. $2 A$; see also Groc et al., 2007) did not markedly reduce the distal dendritic HCN1 enrichment that was observed after E2 
treatment. Moreover, GST-RAP alone did not have an effect, nor did Reelin-blocking CR-50 antibodies (Ogawa et al., 1995) alter HCN1 distribution in our cultures. As these findings are discrepant with the findings of Kupferman and colleagues, and because these discrepancies could have been caused by different experimental conditions in vitro, we additionally examined an experimental mouse model in which Reelin was absent in vivo (LaneDonovan et al., 2015). In these mice, deletion of the reelin gene was induced by tamoxifen at $\sim 2$ months of age, i.e., after hippocampal maturation is completed, resulting in absence of Reelin during adulthood in a hippocampus with an otherwise normal cytoarchitecture (Fig. 3C). Notably, an altered distribution of HCN1 or TRIP8b was not detectable in CA1 of the Reelin-deficient mice (Fig. 4). Taken together, these findings argue against an essential role of Reelin for the establishment and the maintenance of the somatodendritic HCN1 gradient in CA1.

What could be the reasons for the discrepancies between our study and the data by Kupferman et al. (2014)? These authors have based their conclusion mainly on two observations. (1) After viral knockdown of Dab1 in mice, HCN1 expression was selectively diminished and $I_{h}$ reduced in CA1 s/m and in the distal dendrites of neocortical layer 5 pyramidal neurons. (2) The HCN1 gradient in CA1 of organotypic hippocampal cultures was abolished after treatment with GST-RAP. In our opinion, both results could be interpreted differently: Dab1, although generally considered a mediator of Reelin signaling, has also alternative functions, as its phosphorylation (i.e., activation) can be induced independent of Reelin, either through LRPs via alternative ligands (Blake et al., 2008; Bock and May, 2016) or through routes that do not require the LRPs, e.g., via amyloid precursor protein (APP; Trommsdorff et al., 1998; Homayouni et al., 1999; Howell et al., 1999; Young-Pearse et al., 2007; Peterziel et al., 2011). Thus, while Kupferman et al. (2014) may be correct in claiming an involvement of Dab1 in the regulation of HCN1 distribution, their conclusion that this is Reelin mediated is not obligatory. Similarly, RAP is a universal inhibitor of lowdensity lipoprotein receptors that, besides blocking Reelin signaling (Gong et al., 2007; Groc et al., 2007), also binds to other members of the LRP family (Herz et al., 1991; Bu and Schwartz, 1998; Hiesberger et al., 1999), including, e.g., Lrp2/megalin, which mediates the endocytic uptake of retinoids and steroids (Willnow et al., 1999) and is expressed in hippocampus (Alvira-Botero et al., 2010). RAP effects, unrelated to Reelin, may therefore have contributed to the results observed by Kupferman et al. (2014), particularly because high RAP concentrations were applied. Clearly, differences regarding the experimental conditions may have contributed to the observed discrepancies in vitro, but these cannot account for the observed absence of an effect of reelin deletion in vivo.

Whereas Reelin was not required for $\mathrm{HCN} 1$ distal dendritic enrichment in CA1, E2 promoted this enrichment via a mechanism that employs GPER1. Estrogens have previously been shown to modulate $I_{h}$ in kisspeptinexpressing neurons of the hypothalamus (Piet et al., 2013;
Zhang et al., 2013) and in Ah-type visceral ganglion neurons (Qiao et al., 2013). In both experimental settings, effects were mainly attributed to E2-induced changes of HCN1 expression levels (Qiao et al., 2013; Zhang et al., 2013), which in the visceral ganglia also involved GPER1 (He et al., 2015). Thus, whereas GPER1-mediated regulation of HCN1 channel function has been shown before, the novelty of our findings lies in the fact that in CA1 this regulation influences the subcellular distribution of the channels. The underlying mechanisms require further elucidation but could include E2-induced modulation of HCN1 binding to the cytoskeleton, which tightly controls HCN1 trafficking and membrane integration via microtubule- and actin-associated mechanisms (Noam et al., 2010). In this scenario, GPER1 could be connected to the cytoskeleton through a variety of intracellular signaling mechanisms, as it activates, e.g., the mitogen-activatedprotein kinase cascade (MAPK; Filardo et al., 2000; Denley et al., 2018) and phosphoinositide-3-kinase (PI3K; Ruiz-Palmero et al., 2013), which also takes part in Reelin signaling (Jossin and Goffinet, 2007; Chai et al., 2009). E2 may further influence the HCN1 channels' association with TRIP8b, which controls HCN1 compartmentalization in a TRIP8b isoform-dependent manner (Lewis et al., 2011; Piskorowski et al., 2011; Wilkars et al., 2012) and is sensitive to environmental changes (Lyman et al., 2017; Frigerio et al., 2018).

In summary, our findings suggest that the subcellular distribution of HCN1 channels in CA1 is influenced by estradiol but does not require Reelin, as previously proposed (Kupferman et al., 2014). Why, then, were there no differences evident in female mice of different estrous cycle stages (proestrus vs. diestrus; Fig. 6)? As already pointed out, it must be considered that hippocampal neurons are themselves capable of synthesizing E2, because they are endowed with all enzymes required for steroid biosynthesis, including aromatase, which converts testosterone to E2 (Prange-Kiel et al., 2003; Hojo et al., 2004; Kretz et al., 2004; Fester et al., 2009). In fact, in hippocampal tissue, E2 concentrations are about six-fold higher than those in the blood plasma (Hojo et al., 2004), suggesting that the endogenously synthesized E2 plays an important role in hippocampal information processing. Hippocampal aromatase, however, is under the control of the hypothalamic-pituitary axis, and its activity and expression adjust to the changing E2 plasma levels during the estrous cycle (Prange-Kiel et al., 2008; Kato et al., 2013). The HCN1 distribution in CA1 does therefore not necessarily reflect the fluctuation of the peripheral hormone levels, because -in both males and females-hippocampal aromatase, which integrates signals from the neuroendocrine (hormonal) and neuronal (activity-dependent) environment (Balthazart and Ball, 2006; Charlier et al., 2015; Fester et al., 2016; Hojo and Kawato, 2018), could balance the effects of the peripheral hormones and act as a local mediator of neuroendocrine status and neuronal activity on hippocampal information processing, e.g., by fine-tuning HCN1 channel distribution in CA1. 


\section{References}

Alcántara S, Ruiz M, D'Arcangelo G, Ezan F, de Lecea L, Curran T, Sotelo C, Soriano E (1998) Regional and cellular patterns of reelin mRNA expression in the forebrain of the developing and adult mouse. J Neurosci 18:7779-7799. Medline

Alvira-Botero X, Pérez-Gonzalez R, Spuch C, Vargas T, Antequera D, Garzón M, Bermejo-Pareja F, Carro E (2010) Megalin interacts with APP and the intracellular adapter protein FE65 in neurons. Mol Cell Neurosci 45:306-315. CrossRef Medline

Anstötz M, Cosgrove KE, Hack I, Mugnaini E, Maccaferri G, Lübke JH (2014) Morphology, input-output relations and synaptic connectivity of Cajal-Retzius cells in layer 1 of the developing neocortex of CXCR4-EGFP mice. Brain Struct Funct 219:2119-2139. CrossRef

Anstötz M, Huang H, Marchionni I, Haumann I, Maccaferri G, Lübke JH (2016) Developmental profile, morphology, and synaptic connectivity of Cajal-Retzius cells in the postnatal mouse hippocampus. Cereb Cortex 26:855-872. CrossRef Medline

Balthazart J, Ball GF (2006) Is brain estradiol a hormone or a neurotransmitter? Trends Neurosci 29:241-249. CrossRef

Bender RA, Baram TZ (2008) Hyperpolarization-activated cyclic nucleotide-gated $(\mathrm{HCN})$ channels in developing neuronal networks. Prog Neurobiol 86:129-140. CrossRef Medline

Bender RA, Zhou L, Wilkars W, Fester L, Lanowski JS, Paysen D, König A, Rune GM (2010) Roles of $17 \beta$-estradiol involve regulation of reelin expression and synaptogenesis in the dentate gyrus. Cereb Cortex 20:2985-2995. CrossRef Medline

Blake SM, Strasser V, Andrade N, Duit S, Hofbauer R, Schneider WJ, Nimpf J (2008) Thrombospondin-1 binds to ApoER2 and VLDL receptor and functions in postnatal neuronal migration. EMBO $\mathrm{J}$ 27:3069-3080. CrossRef Medline

Bock HH, May P (2016) Canonical and non-canonical reelin signaling. Front Cell Neurosci 10:166. doi: 10.3389/fncel.2016.00166. CrossRef Medline

Brewster AL, Chen Y, Bender RA, Yeh A, Shigemoto R, Baram TZ (2007) Quantitative analysis and subcellular distribution of mRNA and protein expression of the hyperpolarization-activated cyclic nucleotide-gated channels throughout development in rat hippocampus. Cereb Cortex 17:702-712. CrossRef Medline

Byers SL, Wiles MV, Dunn SL, Taft RA (2012) Mouse estrous cycle identification tool and images. PLoS One 7:e35538. doi: 10.1371. CrossRef Medline

Charlier TD, Cornil CA, Patte-Mensah C, Meyer L, Mensah-Nyagan AG, Balthazart J (2015) Local modulation of steroid action: rapid control of enzymatic activity. Front Neurosci 9:83. doi: 10.3389/ fnins.2015.00083.

Bu G, Schwartz AL (1998) RAP, a novel type of ER chaperone. Trends Cell Biol 8:272-276. Medline

Chai X, Förster E, Zhao S, Bock HH, Frotscher M (2009) Reelin stabilizes the actin cytoskeleton of neuronal processes by inducing n-cofilin phosphorylation at serin-3. J Neurosci 29:288-299. CrossRef Medline

D'Arcangelo G, Miao GG, Chen SC, Soares HD, Morgan JI, Curran T (1995) A protein related to extracellular matrix proteins deleted in the mouse mutant reeler. Nature 374:719-723. CrossRef

D’Arcangelo G, Nakajima K, Miyata T, Ogawa M, Mikoshiba K, Curran T (1997) Reelin is a secreted glycoprotein recognized by the CR-50 monoclonal antibody. J Neurosci 17:23-31. CrossRef

Denley MCS, Gatford NJF, Sellers KJ, Srivastava DP (2018) Estradiol and the development of the cerebral cortex. Front Neurosci 12: 245. doi: 10.3389/fnins.2018.00245. CrossRef Medline

Del Río JA, Martínez A, Fonseca M, Auladell C, Soriano E (1995) Glutamate-like immunoreactivity and fate of Cajal-Retzius cells in the murine cortex as identified with calretinin antibody. Cereb Cortex 5:13-21. Medline

Fester L, Brandt N, Windhorst S, Pröls F, Bläute C, Rune GM (2016) Control of aromatase in hippocampal neurons. J Steroid Biochem Mol Biol 160:9-14. CrossRef Medline
Fester L, Zhou L, Bütow A, Huber C, von Lossow R, Prange-Kiel J, Jarry H, Rune GM (2009) Cholesterol-promoted synaptogenesis requires the conversion of cholesterol to estradiol in the hippocampus. Hippocampus 19:692-705. CrossRef

Filardo EJ, Quinn JA, Bland KI, Frackelton AR (2000) Estrogen induced activation of Erk-1 and Erk-2 requires the G protein-coupled receptor homolog, GPR30, and occurs via trans-activation of the epidermal growth factor receptor through release of HB-EGF. Mol Endocrinol 14:1649-1660. CrossRef

Förster E, Tielsch A, Saum B, Weiss KH, Johanssen C, Graus-Porta D, Müller U, Frotscher M (2002) Reelin, Disabled 1, and beta 1 integrins are required for the formation of the radial glial scaffold in the hippocampus. Proc Natl Acad Sci 99:13178-13183.

Förster E, Zhao S, Frotscher M (2006) Laminating the hippocampus. Nat Rev Neurosci 7:259-267. CrossRef Medline

Frigerio F, Flynn C, Han Y, Lyman K, Lugo JN, Ravizza T, Ghestem A, Pitsch J, Becker A, Anderson AE, Vezzani A, Chetkovich D, Bernard C (2018) Neuroinflammation alters integrative properties of rat hippocampal pyramidal cells. Mol Neurobiol 55:7500-7511. doi: 10.1007/s12035-018-0915-1

Gong C, Wang TW, Huang HS, Parent JM (2007) Reelin regulates neuronal progenitor migration in intact and epileptic hippocampus. J Neurosci 27:1803-1811. CrossRef Medline

Groc L, Choquet D, Stephenson FA, Verrier D, Manzoni OJ, Chavis P (2007) NMDA receptor surface trafficking and synaptic subunit composition are developmentally regulated by the extracellular matrix protein reelin. J Neurosci 27:10165-10175. CrossRef Medline

He JL, Li JN, Zuo CM, Wang LQ, Wen X, Zuo M, Guan J, Wu D, Song DX, Yu X, Qu MY, Liu Y, Qiao GF, Li BY (2015) Potentiation of $17 \beta$-estradiol on neuroexcitability by $\mathrm{HCN}$-mediated neuromodulation of fast-afterhyperpolarization and late-afterdepolarization in low-threshold and sex-specific myelinated Ah-type baroreceptor neurons via GPR30 in female rats. Int J Cardiol 182:174-178. CrossRef Medline

Herz J, Chen Y (2006) Reelin, lipoprotein receptors and synaptic plasticity. Nat Rev Neurosci 7:850-859. CrossRef Medline

Herz J, Goldstein JL, Strickland DK, Ho YK, Brown MS (1991) 39-kDa protein modulates binding of ligands to low density lipoprotein receptor-related protein $/ \alpha_{2}$-macroglobulin receptor. J Biol Chem 266:21232-21238

Hiesberger T, Trommsdorff M, Howell BW, Goffinet A, Mumby MC, Cooper JA, Herz J (1999) Direct binding of reelin to VLDL receptor and ApoE receptor 2 induces tyrosine phosphorylation of disabled-1 and modulates tau phosphorylation. Neuron 24:481489. Medline

Hoglund A (1972) A staining method for vaginal smears. Int J Fertil 17:127-130.

Hojo Y, Kawato S (2018) Neurosteroids in hippocampus of male and female rodents: biosynthesis and actions of sex steroids. Front Endocrinol 9:183. doi: 10.3389/fendo.2018.00183. CrossRef Medline

Hojo Y, Hattori T, Enami T, Furukawa A, Suzuki K, Ishii HT, Mukai H, Morrison JH, Janssen WG, Kominami S, Harada N, Kimoto T, Kawato S (2004) Adult male rat hippocampus synthesizes estradiol from pregnenolone by cytochromes P45017alpha and P450 aromatase localized in neurons. Proc Natl Acad Sci USA 101:865870. CrossRef Medline

Homayouni R, Rice DS, Sheldon M, Curran T (1999) Disabled-1 binds to the cytoplasmic domain of amyloid precursor-like protein $1 . \mathrm{J}$ Neurosci 19:7507-7515. Medline

Howell BW, Lanier LM, Frank R, Gertler FB, Cooper JA (1999) The disabled 1 phosphotyrosine-binding domain binds to the internalization signals of transmembrane glycoproteins and to phospholipids. Mol Cell Biol 19:5179-5188. CrossRef

Jossin Y, Goffinet AM (2007) Reelin signals through phosphatidylinositol-3-kinase and Akt to control cortical development and through mTor to regulate dendritic growth. Mol Cell Biol 27:7113-7124. CrossRef Medline 
Kato A, Hojo Y, Higo S, Komatsuzaki Y, Murakami G, Yoshino H, Uebayashi M, Kawato S (2013) Female hippocampal estrogens have a significant correlation with cyclic fluctuation of hippocampal spines. Front Neural Circuits 7:149. doi:10.3389/fncir.2013.00149. CrossRef Medline

Kretz O, Fester L, Wehrenberg U, Zhou L, Brauckmann S, Zhao S, Prange-Kiel J, Naumann T, Jarry H, Frotscher M, Rune GM (2004) Hippocampal synapses depend on hippocampal estrogen synthesis. J Neurosci 24:5913-5921. CrossRef Medline

Kupferman JV, Basu J, Russo MJ, Guevarra J, Cheung SK, Siegelbaum SA (2014) Reelin signaling specifies the molecular identity of the pyramidal neuron distal dendritic compartment. Cell 158: 1335-1347. CrossRef Medline

Lane-Donovan C, Philips GT, Wasser CR, Durakoglugil MS, Masiulis I, Upadhaya A, Pohlkamp T, Coskun C, Kotti T, Steller L, Hammer RE, Frotscher M, Bock HH, Herz J (2015) Reelin protects against amyloid $\beta$ toxicity in vivo. Sci Signal 8:ra67. doi: 10.1126/scisignal.aaa6674. CrossRef

Lee GH, d'Arcangelo G (2016) New insights into reelin-mediated signaling pathways. Front Cell Neurosci 10:122. doi: 10.3389/ fncel.2016.00122. CrossRef Medline

Lewis AS, Vaidya SP, Blaiss CA, Liu Z, Stoub TR, Brager DH, Chen X, Bender RA, Estep CM, Popov AB, Kang CE, Van Veldhoven PP, Bayliss DA, Nicholson DA, Powell CM, Johnston D, Chetkovich DM (2011) Deletion of hyperpolarization-activated cyclic nucleotide-gated channel auxiliary subunit TRIP8b impairs hippocampal Ih localization and function and promotes antidepressant behavior in mice. J Neurosci 31:7424-7440. CrossRef Medline

Lörincz A, Notomi T, Tamás G, Shigemoto R, Nusser Z (2002) Polarized and compartment-dependent distribution of HCN1 in pyramidal cell dendrites. Nat Neurosci 5:1185-1193. CrossRef Medline

Lyman KA, Han Y, Chetkovich DM (2017) Animal models suggest the TRIP8b-HCN interaction is a therapeutic target for major depressive disorders. Expert Opin Ther Targets 21:235-237. CrossRef Medline

Magee JC (1999) Dendritic Ih normalizes temporal summation in hippocampal CA1 neurons. Nat Neurosci 2:508-514. CrossRef

Magee JC, Johnston D (2005) Plasticity of dendritic function. Curr Opin Neurobiol 15:334-342. CrossRef Medline

Noam Y, Zha Q, Phan L, Wu RL, Chetkovich DM, Wadman WJ, Baram TZ (2010) Trafficking and surface expression of hyperpolarization-activated cyclic nucleotide-gated channels in hippocampal neurons. J Biol Chem 285:14724-14736. CrossRef Medline

Nolan MF, Malleret G, Dudman JT, Buhl DL, Santoro B, Gibbs E, Vronskaya S, Buzsáki G, Siegelbaum SA, Kandel ER, Morozov A (2004) A behavioral role for dendritic integration: HCN1 channels constrain spatial memory and plasticity at inputs to distal dendrites of CA1 pyramidal neurons. Cell 119:719-732. CrossRef Medline

Notomi T, Shigemoto R (2004) Immunohistochemical localization of $\mathrm{I}_{\mathrm{h}}$ channel subunits, HCN1-4, in the rat brain. J Comp Neur 471: 241-276. CrossRef Medline

Nusser Z (2012) Differential subcellular distribution of ion channels and the diversity of neuronal function. Curr Opin Neurobiol 22: 366-371. CrossRef Medline

Ogawa M, Miyata T, Nakajima K, Yagyu K, Seike M, Ikenaka K, Yamamoto H, Mikoshiba K (1995) The reeler gene-associated antigen on Cajal-Retzius neurons is a crucial molecule for laminar organization of cortical neurons. Neuron 14:899-912. Medline

Pape HC (1996) Queer current and pacemaker: the hyperpolarization-activated cation current in neurons. Annu Rev Physiol 58:299-327. CrossRef Medline

Pesold C, Impagnatiello F, Pisu MG, Uzunov DP, Costa E, Guidotti A, Caruncho HJ (1998) Reelin is preferentially expressed in neurons synthesizing gamma-aminobutyric acid in cortex and hippocampus of adult rats. Proc Natl Acad Sci USA 95:3221-3226. Medline

Peterziel H, Sackmann T, Strelau J, Kuhn PH, Lichtenthaler SF, Marom K, Klar A, Unsicker K (2011) F-spondin regulates neuronal survival through activation of disabled-1 in the chicken ciliary ganglion. Mol Cell Neurosci 46:483-497. CrossRef Medline

Piet R, Böhm U, Herbison AE (2013) Estrous cycle plasticity in the hyperpolarization-activated current $\mathrm{Ih}$ is mediated by circulating $17 \beta$-estradiol in preoptic area kisspeptin neurons. J Neurosci 33:10828-10839. CrossRef

Piskorowski R, Santoro B, Siegelbaum SA (2011) TRIP8b splice forms act in concert to regulate the localization and expression of HCN1 channels in CA1 pyramidal neurons. Neuron 70:495-509. CrossRef Medline

Pohlkamp T, Dávid C, Cauli B, Gallopin T, Bouché E, Karagiannis A, May P, Herz J, Frotscher M, Staiger JF, Bock HH (2014) Characterization and distribution of Reelin-positive interneuron subtypes in the rat barrel cortex. Cereb Cortex 24:3046-3058. CrossRef Medline

Poolos NP, Migliore M, Johnston D (2002) Pharmacological upregulation of h-channels reduces the excitability of pyramidal neuron dendrites. Nat Neurosci 8:767-774. CrossRef

Prange-Kiel J, Jarry H, Schoen M, Kohlmann P, Lohse C, Zhou L, Rune GM (2008) Gonadotropin-releasing hormone regulates spine density via its regulatory role in hippocampal estrogen synthesis. $J$ Cell Biol 180:417-426.

Prange-Kiel J, Wehrenberg U, Jarry H, Rune GM (2003) Para/autocrine regulation of estrogen receptors in hippocampal neurons. Hippocampus 13:226-234. CrossRef Medline

Ruiz-Palmero I, Hernando M, Garcia-Segura LM, Arevalo MA (2013) $G$ protein-coupled estrogen receptor is required for the neuritogenic mechanisms of $17 \beta$-estradiol in developing hippocampal neurons. Mol Cell Endocrinol 372:105-115. CrossRef

Qiao GF, Qian Z, Sun HL, Xu WX, Yan ZY, Liu Y, Zhou JY, Zhang HC, Wang LJ, Pan XD, Fu Y (2013) Remodeling of hyperpolarizationactivated current, Ih, in Ah-type visceral ganglion neurons following ovariectomy in adult rats. PLoS One 8:e71184. doi: 10.1371. CrossRef Medline

Robinson RB, Siegelbaum SA (2003) Hyperpolarization-activated cation currents: from molecules to physiological function. Annu Rev Physiol 65:453-480. CrossRef Medline

Scharfman H, MacLusky NJ (2006) Estrogen and brain-derived neurotrophic factor (BDNF) in hippocampus: complexity of steroid hormone-growth factor interactions in the adult CNS. Front Neuroendocrinol 27:415-435. CrossRef Medline

Shah MM (2014) Cortical HCN channels: function, trafficking and plasticity. J Physiol 592:2711-2719. Medline

Shin M, Chetkovich DM (2007) Activity-dependent regulation of $h$ channel distribution in hippocampal CA1 pyramidal neurons. J Biol Chem 282:33168-33180. CrossRef Medline

Tissir F, Goffinet AM (2003) Reelin and brain development. Nat Rev Neurosci 4:496-505. CrossRef Medline

Trommsdorff M, Borg JP, Margolis B, Herz J (1998) Interaction of cytosolic adaptor proteins with neuronal apolipoprotein $\mathrm{E}$ receptors and the amyloid precursor protein. J Biol Chem 273:3355633560. Medline

Vaidya SP, Johnston D (2013) Temporal synchrony and gamma-totheta power conversion in the dendrites of CA1 pyramidal neurons. Nat Neurosci 16:1812-1820. CrossRef Medline

Vierk R, Brandt N, Rune GM (2014) Hippocampal estradiol synthesis and its significance for hippocampal synaptic stability in male and female animals. Neuroscience 274:24-32. CrossRef Medline

Waters EM, Thompson LI, Patel P, Gonzales AD, Ye H, Filardo EJ, Clegg DJ, Gorecka J, Akama KT, McEwen BS, Milner TA (2015) G protein-coupled estrogen receptor 1 is anatomically positioned to modulate synaptic plasticity in the mouse hippocampus. J Neurosci 35:2384-2397. CrossRef Medline

Wilkars W, Liu Z, Lewis AS, Stoub TR, Ramos EM, Brandt N, Nicholson DA, Chetkovich DM, Bender RA (2012) Regulation of axonal trafficking of $\mathrm{HCN} 1$ channels in perforant path involves expression of specific TRIP8b isoforms. PLoS One 7:e32181. CrossRef Medline 
Willnow TE, Nykjaer A, Herz J (1999) Lipoprotein receptors: new roles for ancient proteins. Nat Cell Biol 1:E157-E162. CrossRef Medline

Woolley CS, McEwen BS (1992) Estradiol mediates fluctuation in hippocampal synapse density during the estrous cycle in the adult rat. J Neurosci 12:2549-2554.

Yague JG, Muñoz A, de Monasterio-Schrader P, Defelipe J, GarciaSegura LM, Azcoitia I (2006) Aromatase expression in the human temporal cortex. Neuroscience 138:389-401. CrossRef Medline

Young-Pearse TL, Bai J, Chang R, Zheng JB, Lo Turco JJ, Selkoe DJ (2007) A critical function for beta-amyloid precursor protein in neuronal migration revealed by in utero RNA interference. J Neurosci 27:14459-14469. CrossRef

Zha Q, Brewster AL, Richichi C, Bender RA, Baram TZ (2008) Activity-dependent heteromerization of the hyperpolarizationactivated, cyclic-nucleotide gated $(\mathrm{HCN})$ channels: role of $\mathrm{N}$-linked glycosylation. J Neurochem 105:68-77. CrossRef Medline

Zhang C, Tonsfeldt KJ, Qu J, Bosch MA, Kobayashi K, Steiner RA, Kelly MJ, Rønnekleiv OK (2013) Molecular mechanisms that drive estradiol-dependent burst firing of Kiss1 neurons in the rostral periventricular preoptic area. Am J Physiol Endocrinol Metab 305: E1384-E1397. CrossRef 